\begin{tabular}{c}
\hline Review of \\
ECONOMICS \\
and \\
INSTITUTIONS
\end{tabular}

\title{
Measures of R\&D Tax Incentives for OECD Countries
}

\author{
Russell Thomson $\bowtie$ \\ Melbourne Institute of Applied Economic and Social Research, \\ Intellectual Property Research Institute of Australia (IPRIA), \\ University of Melbourne
}

\begin{abstract}
This paper outlines tax policy details from 26 OECD countries between 1980 and 2006 and provides summary quantitative measures of their relative generosity. Separate measures for the after-tax cost of labour, other current expenditure, machinery equipment and buildings and structures are presented and also a measure of tax policy applicable to multinational subsidiaries undertaking R\&D on behalf of the parent firm. The purpose of this paper is to make this data available for other researchers.
\end{abstract}

JEL classification: $\mathrm{H} 25 ; \mathrm{O} 31$

Keywords: R\&D, tax incentives, data

This data was complied as part of the Authors PhD undertaken at the Arndt-Corden Division of Economics, Research School of Pacific and Asian Studies at the Australian National University. The author is grateful to Hal Hill, Paul Jensen, Prema-Chandra Athukorala. Particular thanks to Jacek Warda and Adrian Sawyer for assistance.

Address: Melbourne Institute of Applied Economic and Social Research, University of Melbourne. Victoria 3010 Australia (Phone: + 0383442198 Fax + 038344 2111, E-mail: russell.thomson@unimelb.edu.au)

\section{Recommended Citation}

Thomson, R. (2013). Measures of R\&D Tax Incentives for OECD Countries. Review of Economics and Institutions, 4(3), Article 4. doi: 10.5202/rei.v4i3.144. Retrieved from http://www.rei.unipg.it/rei/article/view/144 


\section{Introduction}

Tax policy is a common mechanism through which governments aim to induce higher levels of R\&D investment. This paper documents relevant policy details in 26 OECD countries between 1980 and 2006 and provides a summary quantitative measure of the effective subsidy rate in each country on four classes of expenditure: labour expenses; other current expenses; machinery and equipment and buildings and structures. The measures incorporate corporate income tax; depreciation as well as explicit incentive schemes such as credits.

Measures of the effective subsidy afforded by tax policy, such as those provided in this article, are needed to estimate the effectiveness of fiscal subsidies. This remains an active area of research, probably reflecting the adoption and ongoing reform of fiscal incentives many countries, including most all OECD member states. Ostensibly exogenous variation in the relative subsidy rate across jurisdictions provides a useful basis for identification. Cross-country analysis has the advantage over firm level studies that they avoid the fact that R\&D investment and its after tax cost are jointly determined (see Hall 1995). Cross-country estimates of the short-run elasticity of R\&D investment with respect to its tax-price are between 15 and 30 (Bloom et al. 2002; Guellec and van Pottlesberghe 2003). However, since major revisions to tax policy are rare, cross-country analysis may be sensitive to outliers (Thomson 2013a). Incorporating variation in policy at across sub-national regions may be one way to improve upon the cross-country approach (see Wilson 2009). Alternatively, an in industry-specific measure of the effective subsidy rate can be derived by incorporating differences across expenditure types (e.g., R\&D equipment versus labor) and systematic variation in expenditure mix by industry (see Thomson 2013a).

There are a number of important issues around the efficacy of fiscal incentives where the literature has not reached consensus. One issue is whether subsidies may drive up the price of inelastic inputs (such as skilled researchers) rather than effect increased real R\&D investment (see Goolsbee 1998; Wolff and Reinthaler 2008; Thomson and Jensen 2013). More research is also needed to understand how domestic and foreign tax incentives might be affecting the location of increasingly globally mobile R\&D investment (see for e.g., Athukorala and Kohpaiboon 2008; Thomson 2013b). The data presented in this article may also find utility in applications where R\&D tax policy may be a confounding factor. This is particularly relevant to evaluations of government grant and subsidy programs, higher education research appropriations and intellectual property right regimes. Since these policy levers all relate to inducing private sector $R \& D$, they are often reformed contemporaneously. That is, variation in these different policies may well be correlated. For example, governments may introduce more generous R\&D tax incentives while at the same time reducing direct gov- 
ernment R\&D grants.

Data on the average subsidy rate for $R \& D$ fiscal incentives have been published by the OECD for some years (see OECD 2006 p. 242) 1] Unlike the OECD data this article presents separate measures for four types of expenditure as well as a separate measure for the effective subsidy rate for R\&D offshoring as well as covering an expanded number of country-year observations calculated based on consistent methodology and assumptions. Most importantly, unlike the OECD data, all background data used in the calculations are presented.

\section{The measure}

The measures complied here are based on the tax component of Jorgenson (1963)'s user cost of capital which was first adapted to R\&D investment by McFetrdige and Warda (1983)..$^{2}$ Variations of the methodology have been widely used to measure tax benefits for R\&D at the firm, state and national level (see for example Bloom et al., 2002; Guellec and van Pottelsberghe, 2003; Wilson, 2009). The formula for the measure is given by

$$
b=\frac{A T C}{1-C I T}
$$

where $A T C$ is after tax cost of $\mathrm{R} \& \mathrm{D}$ allowing for reductions in corporate income tax liabilities that result from the expenditure; and CIT is the corporate income tax rate. The measure represents the before tax project hurdle rate i.e., the minimum before tax return the marginal R\&D investment must generate to be financially viable after tax (Warda 2006). The most demanding component to calculate for the measure is the after-tax cost of $R \& D$, which is discussed in some detail below.

The after-tax cost of R\&D investment (denoted by $A T C$ ) can be expressed in general terms as:

$$
A T C=1-N V T \text { Deductable } \times C I T-\text { Credit }
$$

This states that a firm's after-tax cost is reduced by allowable deductions multiplied by the corporate income tax rate $(C I T)$ as well as any explicit tax credits. The value of deductions is determined by: (1) the net present value of the stream of allowable claims; and (2) any augmented deduction policy. Augmented deduction is where claimable amounts are multiplied by a factor greater than 100 percent. Note that firms receive an implicit subsidy if the rate of depreciation allowable for tax purposes is greater than

${ }^{1}$ Unpublished OECD data are also cited in some studies (Guellec and Pottelsberghe 2003; Falk 2006)

2 The authors refer to the measure as the 'b-index' which is short for the benefit cost ratio at which an R\&D investment opportunity becomes viable after tax (Warda 2001). 
the actual rate of depreciation of the intangible asset (technology) which the $R \& D$ investment created. Since $R \& D$ generally produces a stream of benefits persisting for some duration, allowing 100 percent of expenses to be deducted in the year they are incurred represents an implicit subsidy.

Allowable depreciation rates differ across different types of expenditure and by country. Previous authors, including the OECD, follow the assumption that that representative R\&D investment is comprised of $90 \%$ current expenditure, two thirds of which represents the wages of researchers $(60 \%$ total expenditure). The remaining 10 percent of total expenditure is assumed to comprise machinery and equipment (M\&E) and buildings and structures $(B \& S)$ in equal portions. This is reflective of the approximate composition of expenditure reported in industrial surveys (McFetridge and Warda 1983, Bloom et al. 2002). In this paper the tax price of each expenditure type is presented separately thereby allowing researchers to vary the weighting or otherwise use these measures separately. The tax price of international contract $R \& D$ reported in this document uses the standard weighting.

The allowable rate of deduction as well as eligibility to additional credits for each expenditure type was identified from a range of sources. In all cases in our sample, labour expenses could be deducted at 100 per cent in the year they are incurred (or at a higher rate where augmented deduction is allowable). The net present value $(N P V)$ of deductions available for tangible capital depends on the allowable depreciation schedule, which is defined in the national tax code ${ }^{3}$ Relevant augmented deductions are applied to the $N P V$ determined by the allowable depreciation schedule.

A common type of policy, known as an 'incremental scheme', is where only $R \& D$ expenditure over-and-above a defined base level is eligible for credits or augmented deductions. A common way to define the base is the average expenditure in the previous three years. This type of incremental scheme presents a complexity to modelling the effective incentive power of tax policy. None of the R\&D investment made by firms that do not increase their expenditure over time is eligible for any special treatment. For a firm which increases nominal spending, the marginal $R \& D$ dollar is eligible for the tax credit, but also reduces the share of future expenditure which will be eligible. Following past cross-country studies we model incremental schemes, where the base is defined as a trailing k-period moving average, the credit or deduction rate is multiplied by $1-\frac{1}{k} \sum_{i=1}^{k}(1+r)^{-i}$ which reflects the marginal value of an incremental incentive for a firm with increasing $R \& D$ expenditure or equivalently the average share of eligible expenditure for a firm maintaining constant real R\&D expenditure (see Richardson and

3 The formulae used are: $N P V_{S L}=\frac{1}{T} \frac{1-(1+r)^{-T}}{r /(1+r)}$ and $N P V_{D B}=d \frac{(1+r)}{d+r}$ for straight line and declining balance depreciation respectively, where $r$ is the discount rate, or required rate of return. 
Wilkie, 1995). Consistent with past cross country studies figures reported here use a fixed 10 percent discount rate.

In assembling the data, careful attention was paid to identify any special treatment or exemption for foreign contract R\&D - any R\&D which is financed by a foreign firm or where the resultant IP is vested with a company abroad. No exclusions based on foreign ownership were identified in any country. However, the tax systems in France, Korea and Switzerland allow, under some conditions, for R\&D active foreign firms to be granted tax holidays (Rashkin 2007). Until 2007 eligiblity for the tax incentive in Australia depended on the resultant IP being vested with the researching firm, which means R\&D performed for the MNE headquarters is not eligible (BIE 1993, ATO 2002). A special scheme for foreign contract R\&D was introduced in Australia in 2007. The scheme in Portugal requires that the R\&D be at least 25 per cent self-financed (IBFD 2004 p. 154). No information regarding such exclusions in any other countries was identified. The absence of restrictions was confirmed in the case of Austria, Canada, Ireland and the UK (Canadian Embassy Berlin 2003; IBFD 2004; IRC 2005; McAlpine 2005). In some countries, including Belgium and France, taxpayers cannot claim R\&D expenses that are contracted out to other firms (IBFD 2004). However, this does not appear to limit the contracted firm from claiming expenses. In the case of France, some ambiguity existed prior to 2007, though it seems firms conducting R\&D under contract did claim the tax credit (DTT 2008).

All tax policy information and calculated measures are included the appendix. In the data table, CIT is the headline corporate income tax rate applied in calculations. The column entitled 'labour' reports the tax price of labour related R\&D expenses (i.e., equation 1). Oth. Curr. is the tax price of other current (non labour) expenses. These are the same as labour expenses in all countries except where there exist special credits or deductions for wages and overheads or per employee (such as the Netherlands). $\mathrm{M} \& \mathrm{E}$ is the tax price of machinery and equipment used for the purposes of $R \& D$ and $B \& S$ is the tax price of buildings and structures. The final column entitled 'Foreign' reports a measure for tax price for R\&D expenditure that applicable to cross border R\&D, that is, where the firm undertaking the $R \& D$ is domiciled in a different country to the firm which will own the resultant intellectual property. The principal difference is that such $R \& D$ is not eligible for the Australian R\&D tax concession. This measure uses the standard 60:30:5:5 weighting across expenditure types.

\section{Caveats to the measures reported}

The measure presented aims to capture the principal features of depreciation, deductions and special credits applicable to all large firms. It is important to acknowledge the limitations of the measure and potential sources of measurement error. These are outlined below. 
The calculations assume that firms can benefit fully from the incentive, i.e., it assumes firms have sufficient tax liabilities to claim the full amount of R\&D tax incentives in the current year. Also, the standard methodology does not consider caps and floors in the scheme. Observe that where caps are binding, the after tax cost of marginal expenditure is zero, while the average after-tax cost depends on by how much the cap has been exceeded. While the measure incorporates differences in rules relating to the eligibility of current and fixed capital assets, it does not incorporate subtle and complex differences in the definition of qualifying expenditure. The definition of eligible expenditure is generally based on the standards outlined in the Frascati Manual (OECD 2002a). Qualifying expenditure must commonly demonstrate characteristics such as technical risk, novelty and or creativity (Rashkin 2007). However, the definition of qualifying expenditure differs between jurisdictions. This is a particularly difficult measurement issue to address because tax law is not always perfectly codified. There is often scope for interpretation of guidelines by both claimants and administrative agencies. For the same reason identifying 'typical' depreciation schedules is also inherently subject to some measurement error.

The measures of R\&D tax policy constructed here do not incorporate differences in tax treatment of dividends or withholding taxes on international transfers of profit. There are two important cases where interaction between these taxes and $R \& D$ incentives can reduce the effective value of $R \& D$ tax incentives to shareholders. The issue arises where shareholders receive tax relief on dividend income commensurate with the CIT already paid by the company. Dividend imputation systems (DIS) reduce the effective value of the tax incentives to shareholders have been in place in some countries over some of the study period including Australia, New Zealand, France and Canada. DIS allow shareholders receiving dividends to be allocated tax credits for CIT already paid on company profit. DIS aim to avoid double taxation of company profits. With complete imputation, taxpaying shareholders are indifferent to $R \& D$ tax incentives provided on company profit because a decrease in CIT liabilities, resulting from an R\&D tax incentive policy, can lead to a direct increase in the tax paid on dividends. MNEs repatriating income can face an analogous 'washout' of host country R\&D tax incentives (see Hall 1995).

Several nations provide fiscal incentives with objectives other than purely inducing additional R\&D investment. They offer incentives targeted at encouraging collaboration between domestic firms and either the government sector, the tertiary education sector or international research projects. For example, Denmark and Hungary offer incentives for collaboration with the higher education sector at 150\% and 400\%, respectively (Warda 2006 p. 14). These are not modelled, primarily because there is no obvious way to model these in a comparable manner.

Finally, the measures do not reflect features of taxes levy's by sub-national 
governments offer R\&D tax incentives. This primarily affects federal systems of Canada and the United States $4^{4}$ These sub-national policies were not modelled because of practical difficulties in collecting historical data on sub-national policies. Additionally, incorporating state-level incentive rates into national measures would require weighting tax policy against the proportion of national R\&D performed in each region. Often state incentives reduce eligibility to national incentives meaning this is unlikely to be a serious limitation. For example, in the case of Canada, the figures estimated here are within 3 decimal places of recent estimates of the b-index for the state of Ontario published by the OECD.

\section{Country tax policy details and data sources}

Detail of national tax codes come from a wide range of sources including McFetridge and Warda (1983) OECD (1996; 2000; 2002b; 2005), Warda (1996a; 1996b; 1999; 2001; 2003; 2006), ETAN (1999a; 1999b), IBFD (2004; 2007).

Corporate income tax $(C I T)$ is compiled from a number of sources including: University of Michigan World Tax Database (WTD 2007), World Bank World Development Indicators (WDI), OECD Tax Database (OECD 2007) and the KPMG Corporate Tax Rate Survey (KPMG 2007). Unless otherwise stated, data applied are based on central government tax rates only from WTD (2007) extended for the more recent years using OECD (2007). Cases where methodology deviates from this, for example to account for significant taxes levied at the regional level, are detailed.

In what follows incremental incentive schemes are always based on nominal expenditure. Credits are untaxed unless otherwise stated. In some instances it was difficult to confirm 'typical' depreciation schedules for fixed capital assets. The depreciation applied is documented based on the information available. Status quo is assumed unless evidence of a policy shift is available.

Australia. R\&D tax policy: A 150\% deduction introduced 1 July 1985 and then reduced to $125 \%$ from 1 July 1997 . From 1 July 2001, companies could also claim an additional 50\% (175\% total) deduction on incremental expenditure above a 3 year moving average base. Foreign contract R\&D: prior to 2007 foreign contract R\&D not eligible (BIE 1993; ATO 2002). Depreciation: M\&E (1980-1996) 3 years straight line (SL), (1996- ) 5 years SL. B\&S: (1980-1986) 3 years SL (Lattimore 1997 p. 94). (1987-) 40 years SL. CIT:5 $46 \%$ (1980-86), 49\% (1987-88), 39\% (1989-1993), 33\% (1994-95), 36\% (1996-1999),

\footnotetext{
${ }^{4}$ In Australia, State governments do not levy corporate income tax.

${ }^{5}$ Unless otherwise stated, all CIT data applied are based on central government tax rates from University of Michigan World Tax Database (WTD 2007) extended for the more recent years using OECD (2007). Other sources include: KPMG Corporate Tax Rate Survey (KPMG 2007) and World Bank World Development Indicators (WDI).
} 
34\% (2000), 30\% (2001-2006) (financial year begins 1 July, for example 1 July 1999- 30 June 2000 is denoted as 1999).

Austria. R\&D tax policy: 1980-1988: 105\% deduction. 1988 - 1999, 112\% deduction. If the innovation was commercialised 'in house' the rate was $118 \%$ which is the rate modeled here. Cited as Tax law BGBL Nr 4/1988 in ETAN (1999a). 2000 - 2006, the concession included two parts, a 125\% deduction available on the volume and $135 \%$ on increments above base expenditure defined as a three year moving average (Law BGBL 28/99). From 2005 , firms could opt to take an $8 \%$ credit (modeled here). Foreign contract R\&D: no restrictions. Depreciation: For the years 1980-1983, all fixed assets are deducted at $80 \%$ in the first year, followed by the remainder over the subsequent 4 years on a straight line basis (Warda 1983). For the period 1984-2006, depreciation is calculated over 5 and 25 years SL for M\&E and B\&S, respectively. CIT: 55\% (1980-88), 30\% (1989-93), 34\% (1994-2004), 25\% (2005-06).

Belgium. R\&D tax policy: McFetridge and Warda (1983) observe that in 1980 a scheme was in place whereby expenditure above the average in the three years to 1976 was eligible for a 15\% augmented deduction (115\% of expenditure deducted from taxable income) ${ }^{6}$ In the absence of additional information the $15 \%$ rate is applied. Foreign contract $R \& D$ : no restrictions. Depreciation: We assume M\&E is depreciated over 3 years SL. B\&S are depreciated over 20 years SL. CIT: 48\% (1980-1982), 45\% 1983-86, 43\% (1987$1989), 41 \%$ (1990), 39\% (1999-2002), 33\% (2003-2006).

Canada. R\&D tax policy: The R\&D tax credit in Canada was introduced in 1966 and has undergone a range of variations since then. Between 1980 and 1982, the scheme consisted of $10 \%$ on volume as well as an incremental credit of $50 \%$ above a three year moving average base. From 1983 the credit is $20 \%$. The R\&D credit in Canada is taxable, in that current allowable deductions are reduced by the value of the credit (Bloom et al. 2002). Foreign contract R\&D: no restrictions. Depreciation: B\&S and M\&E were expensed (deducted at 100\%) M\&E between 1979 and 1987 (Bloom et al. 2002). Since $1987 \mathrm{M} \& \mathrm{E}$ can be deducted in the year it is incurred and B\&S at $4 \%$ on a declining balance basis. CIT:7 $46 \%(1980-86), 45.5 \%(1987), 41.5 \%$ (1988), 38\% (1989-2002), 33\% (2003), 31\% (2004-06).

\footnotetext{
6 Under some conditions eligible expenditure could be scaled up, by a maximum of $50 \%$ meaning that in principle firms could deduct $122.5 \%$ of every incremental dollar (McFetridge and Warda 1983; ETAN 1993b, p. 12). However, a European Commission report (ETAN 1999b) notes that "In practice, however this higher figure is never reached".

7 The headline central government (CG) Corporate Income Tax is applied. In Canada, the CG CIT is generally reduced by $10 \%$ (Provincial abatement) but increased by provincial (sub national) CIT. For example, the state CIT in Ontario has ranged from 12.5 to $13 \%$. Additional features include the rebate for the manufacturing sector that has varied from 2 to $7 \%$ as well as a federal surcharge which has varied from $0-5 \%$ over the period. The headline CG CIT is close to measures taking into account these additional factors that require additional assumptions.
} 
Czech Republic. R\&D tax policy: No special concessions were available between 1993 and 2005. As of 2005 a 200\% deduction is available to all firms. Foreign contract R\&D: no information about restrictions was identified. Depreciation: 5 years SL for M\&E and 30 years SL for B\&S applied over the entire period. CIT: 45\% (1993), 42\% (1994), 41\% (1995), 39\% (199697), 35\% (1998-2000), 31\% (2001-03), 28\% (2004), 26\% (2005), 24\% (2006).

Denmark. R\&D tax policy: No special incentives are modeled. Denmark has had a range of concessions in place, but these have been attached to special conditions, generally relating to encouraging research collaboration both internationally and between tertiary research institutions and private business. Depreciation: Between 1980-1997 all fixed assets are deducted $100 \%$ in the year of expense. For the period 1998- 2006 M\&E and B\&S are deducted according to a 30\% declining balance (DB) and 20 year SL, respectively. CIT: 40\% (1980-85), 50\% (1986-89), 40\% (1990), 38\% (199192), 34\% (1993-98), 32\% (1999-2000), 30\% (2001-04) and 28\% (2005-06).

Finland. R\&D tax policy: Tax Deduction Enhancement 1983-87 allowed firms to deduct $225 \%$ on the first $4 \mathrm{~m} \mathrm{FM}$ and $10 \%$ on amounts above this (ETAN 1999a). In addition a 50\% deduction was available on incremental expenditure above the previous year. It has been suggested that the scheme was ultimately withdrawn on the basis that little impact was observed (ETAN 1999a). The calculations here apply the $10 \%$ rate on the volume plus the 50\% incremental scheme to current expenditure between 1983 and 1987 inclusive. Foreign contract R\&D: no information about restrictions was identified. Depreciation: 25\% DB for M\&E and 20\% DB for B\&S. CIT: 43\% (1980-85), 33\% (1986-89), 25 (1990) 23\% (1991), 19\% (1992), $25 \%$ (1993-1995), 28\% (1996-1999), 29\% (2000-04), 26\% (2005-).

France. R\&D tax policy: For the years 1983-1984, businesses in France could claim a $25 \%$ tax credit on expenditure above the previous year's expenditure (Mulkay and Mairesse 2003). This was increased to 50\% in 1985. Between 1988-90 an alternative credit of $30 \%$ on the increment above expenditure in 1987 was available (Bloom et al. 2002). In 1991, the base for calculating incremental expenditure was changed to be defined as the average of the previous two years (two year moving average; see Mulkay and Mairesse 2003). From 2004 to 2005, firms could claim 5\% on volume and $45 \%$ on incremental expenditure with incremental expenditure defined as a 2 year moving average. In 2006, this was again changed to $10 \%$ on the volume and $40 \%$ on incremental expenditure above a 2 year moving average. Foreign contract R\&D: some ambiguity existed prior to 2007, however firms conducting R\&D under contract did claim the credit (DTT 2008). Foreign firms can be eligible for tax holidays. Depreciation: M\&E and B\&S are depreciated at 4\% DB and 20 years SL respectively. However, between 19831986 B\&S used for scientific research attracted an accelerated depreciation under which $50 \%$ was deducted in the year of expense with the remainder 
deducted over the usual period (Bloom et al. 2002). CIT: 50\% (1980-86), 45\% (1987), 42\% (1988), 39\% (1989), 37\% (1990), 34\% (1991-92), 33\% (1993-2006).

Germany. R\&D tax policy: Germany has had no special concessions Depreciation: Depreciation rates applied are 20\% DB for M\&E and 4\% DB for B\&S. CIT: 61.8\% (1980-1989), 59.7\% (1990-1993), 55.6\% (1994), 59.0\% (19951996), 57.5\%, (1997-98), 52.0\% (1999-2000), 38.0\% (2001-02), 40.0\%, 38.0\% (2004-06), 38.3\% (2006) 8

Greece. R\&D tax policy: Greece has had no special concessions available throughout this period. Depreciation rates of 12.5 years (SL) for buildings. For M\&E immediate deduction is assumed for the period between 1980 and 1998 (consistent with Warda 1996b) and depreciation over 3 years (SL) for the period 1999 to 2006 (consistent with Warda 2001). CIT: 43.4\% (1980-1982), 48.5\% (1983-84), 49.0\% (1985-1988), 46.0\% (1989-1992), 35.0\% (1993-2004), 32.0\% (2005), 29.0\% (2006).

Hungary. R\&D tax policy: 1997-1999 current expenditure can be deducted at a rate of $120 \%$. In 2000 this was increased to $200 \%$ (NKTH 2006). Depreciation: 3 years SL for M\&E and 50 years SL for Buildings. CIT: $40.0 \%$ (1990-1993), 36.0\% (1994), 18.0\% (1995-2003), 16.0\% 2004-2006.

Ireland. R\&D tax policy: Between 1996 and 1998: a special 400\% deduction was available on R\&D expenditure above the previous year (ICSTI 1998; ETAN 1999a). Only companies eligible for the special 10\% CIT were eligible..$^{9}$ The Finance Act 2004 introduced a 20\% tax credit on incremental expenditure. The baseline for calculating incremental expenditure is 2003 for R\&D expenditure incurred in the first 3 years of the scheme (2004 to 2006 , inclusive). Thereafter, the base is defined as the expenditure four years previous. i.e., for 2007 the baseline will be 2004 and for 2008 the base will be 2005, and so on. Foreign contract R\&D: no restrictions. Depreciation: Both $M \& E$ and $B \& S$ are written off in the year it is incurred over the entire period. CIT: Ireland introduced a special tax rate of $10 \%$ nominally for manufacturing companies in 1981. In practice, eligibility extended to most relevant firms as courts deemed businesses in a number of activities not normally regarded as manufacturing as being eligible (Lowtax.net 2008). This is the rate applied in most past studies of tax concessions. In 1980 CIT was the standard $45 \%$.

Italy. R\&D tax policy: Italy had no special tax treatment for R\&D by large firms during the period of study. Depreciation: 10 years (SL) for

${ }^{8}$ CIT data applied for Germany from 1990 is taken from KPMG which include both central government rate and important corporate income taxes that vary by municipality. KPMG do not cover 1990 and 1992, the 1993 figure is extrapolated back as the headline CG CIT is the same in each of these years. Prior to 1990 figures are taken directly from Bloom et al. (2002).

9 The scheme had a relatively low cap (175,000 IEP or about 350,000 USD) and according to the Irish Council for Science, Technology \& Innovation "the deduction still had many restrictions and was little used by either foreign or indigenous research performers." 
M\&E and 33 years (SL) for buildings. CIT: 36.3\% (1980-1981), 38.8\% (1982), 41.3\% (1983), 46.4\% (1984-1990), 47.8\% (1991-1992), 52.2\% (1993-1998), 41.3\% (1998-2000), 40.3\% (2001-2002), 38.3\% (2003), 37.3\% (2004-2006).

Japan. R\&D tax policy: Japan has had a tax incentive for R\&D in place since 1967 (Koga 2003). For the period 1980 to 1998 a 20\% tax credit on incremental expenditure, with the base defined as the largest expenditure reported since 1967, which for the representative firm is the previous year's expenditure. Subject to a maximum cap of $10 \%$ of a company's CIT liabilities. Reform in April 1999 (Koga 2003) reduced the rate to 15\% and the definition of the base was changed. From 1999 the base is as the average of the three maximum R\&D expenses in the past 5 years. From 2004, the rate of the credit is $8-10 \%$ (depending on firm R\&D intensity) plus an additional $2 \%$ "as an aid of overcoming depressed economic situation" (OECD 2006). The average $11 \%$ total tax credit is applied here. Foreign contract R\&D: no information about restrictions was identified. Depreciation: 50 years SL for buildings ${ }^{10}$ and for M\&E. A depreciation schedule of $18 \%$ DB for M\&E for the years 1980-2003, and 50\% thereafter is applied here ${ }^{11}$ CIT: ${ }^{12}$ $53.0 \%$ (1980), 55.2\% (1981-1983), 56.6\% (1984-1986), 55.2\% (1987-1988), 53.0\% (1989), 50.4\% (1990-1997), 47.2\% (1998), 42.4\% (1999-2006).

Korea. R\&D tax policy: An incentive introduced in 1988 allowed firms to claim a credit of $25 \%$ on incremental expenditure above a 2 year moving average base and $5 \%$ on the volume expenditure $(10 \%$ on volume for small firms) (OECD 1998, p. 172). Between 1998 ${ }^{13}$ and 2004 companies could choose between either the $50 \%$ on incremental expenditure or $5 \%$ on the total volume of expenditure. The $50 \%$ incremental rate is applied here as it is the more generous of the two under the current assumptions. The reforms also changed the base to the average of the previous four years (OECD 2000; Sawyer 2004). The rate of the incremental scheme was reduced from 50 to $40 \%$ in 2003 (Rashkin, 2007). Foreign contract R\&D: no information about restrictions was identified. Foreign firms can be eligible for tax holidays. Depreciation: Between 1980 and 1997 depreciation

\footnotetext{
${ }^{10}$ This is based on Warda (1996b) and is also consistent with available figures for b-index published by the OECD.

${ }^{11}$ McFetridge and Warda (1983) suggests this is depreciated "over useful life 4-7 years. This is close NPV to the $18 \%$ DB applied for later periods.

12 Three forms of taxation levied on corporate profits in Japan are considered: central government rate, prefectural tax and citizen's tax. Corporations operating in Japan must also pay prefectural tax. The prefectural tax rate in this study is taken as $12 \%$ (deductible). The inhabitant's tax or enterprise tax is levied as a "surcharge on national income tax. "In this study, Warda (1996b) is followed, applying a rate of $20.7 \%$. Central government rate is taken from the WTD. The eventual series is very close to the Composite CIT reported by KPMG that takes into account these sub-national taxes. However this enabled calculation of an equivalent figure for years that are not included in the KPMG database (1980-1992). There was also a different tax rate applied to retained and distributed profits prior to 1999 this is not modelled here.

${ }^{13}$ Associated with the 'Special Law for S\&T' enacted in 1997.
} 
rates of $22.6 \%$ and $5.6 \% \mathrm{DB}$ are applied for $\mathrm{M} \& \mathrm{E}$ and $\mathrm{B} \& S$ respectively. ${ }^{14}$ For the subsequent decade each are depreciated over 5 years on a SL basis. CIT: 30.0\% (1980-1990), 34.0\% (1991-1993), 32.0\% (1994), 30.0\% (1995), 28.0\% (1996-2001), 27.0\% (2002), 25.0\% (2005).

Mexico. R\&D tax policy: Between 1981 and 1982 (introduced November 1980) Mexico provided a tax credit on durables of $15-20 \%$ (McFetridge and Warda, 1983). The maximum $20 \%$ rate is applied here. There was also a credit of $10 \%$ for payment for 'R\&D services'. These represent contract $R \& D$ or outsourcing part of the $R \& D$ process. McFetridge and Warda (1983) suggests such expenditure comprises around $8 \%$ of total R\&D spending. Between 1983 and 1996 no special incentives were generally available. Between 1997 and 2001 expenditures above a three year moving average were eligible for a 20\% credit (Sawyer 2004). Since 2002 a 30\% credit has been available on expenditure (OECD 2006). Credits are untaxed; i.e., they do not reduce standard deductions. Foreign contract R\&D: no information about restrictions was identified. Depreciation: The depreciation rates applied are 3 and 20 years on a SL basis for M\&E and B\&S, respectively. CIT: 42.0\% (1980-1986), 35.0\% (1987-88), 37.0\% (1989), 36.0\% (1990), $35.0 \%$ (1991-1993), 34.0\% (1994-1998), 35.0\% (1999-2002), 34.0\% (2003), 33.0\% (2004), 30.0\% (2005), 29.0\% (2006).

Netherlands. R\&D tax policy: Netherlands represents an important case study for the effectiveness of R\&D tax incentives. From 1994, R\&D wages attracted a tax credit of $40 \%$ of the first $72,000 \mathrm{ECU}$ and $12.5 \%$ of above (Hall 1995). The 12.5 rate is modeled. This credit applies to salaries and these are assumed to constitute $60 \%$ of total representative R\&D expenditure. The value of the concession increased to $13 \%$ in 2001 and to $14 \%$ from 2004. Foreign contract R\&D: no information about restrictions was identified. Depreciation: Depreciation rates applied are 5 and 25 years on a SL basis for M\&E and B\&S, respectively. CIT: 48.0\% (1980-1983), 43.0\% (1984-85), 42.0\% (1986-88), 35.0\% (1989-1995), 37.0\% (1996), 36.0\% (1997), $35.0 \%$ (1998-2001), 34.5\% (2002-2004), 31.5\% (2005), 29.6\% (2006).

New Zealand. R\&D tax policy: No special concessions or tax credits have been available during the period 1980-2005. The rules for deducting 'current' R\&D expenditure including wages have been subject to some uncertainty, particularly prior to 2001. While the situation prior to 2001 was somewhat ambiguous, a discussion paper prepared by the New Zealand Inland Revenue Department observes that "... although the tax treatment of R\&D expenditure is uncertain, taxpayers are immediately deducting almost all of their R\&D costs" (IRD 2000). Separate provisions (DJ 9 ITA 1994 and

\footnotetext{
${ }^{14}$ This is consistent with Warda (1996b) and others. However, Warda (1983) notes $50 \%$ of these assets are depreciated up front with the remainder depreciated "over their useful lives". In the absence of further guidance, the 1996 information on asset depreciation has been applied back to 1980 .
} 
earlier 144 ITA 1976) existed, allowing deductions for expenditure relating to scientific research. Provisions under ITA 1976 suggest a similar capital test. Depreciation: Following Warda (1996) a representative depreciation schedule of $22 \%$ (DB) is applied for M\&E, and 4\% (DB) for B\&S. CIT: $45.0 \%$ (1980-1985), 48.0\% (1987-88), 28.0\% (1989), 33.0\% (1990-2006).

Norway. R\&D tax policy: 1980-2001 no special concessions. 2002 - current 18\% tax credit (OECD 2006). Depreciation: M\&E and B\&S depreciated at $20 \%$ and $5 \%(\mathrm{DB})$ respectively. CIT: $50.8 \%(1980-1991), 28.0 \%$ (19922006). Before the reform in 1992, basic CIT in Norway was $27.8 \%$ as cited in WTD. Corporations also paid municipal income tax (21\% in 1989) and an additional 2\% surtax (Genser 2001). McFetridge and Warda (1983) also cite the total rate as $51 \%$.

Poland. R\&D tax policy: From July 2005, large firms receive a 30\% tax credit on expenditure "incurred to purchase new technologies" (IBFD online database). Accessibility is limited to firms which obtain at least 50\% of their income from R\&D, the law "enables entrepreneurs to deduct from their tax base expenditures on purchase of new technologies from research units" (OECD 2006, p. 71). As such, it appears this incentive is not available for all 'in house' $R \& D$. The purchase of $R \& D$ services is assumed to constitute $8 \%$ of R\&D costs - analogously to the scheme in Mexico in 1980-82 (discussed above). Foreign contract R\&D: no restrictions identified. Depreciation: prior to the 2005 reform, in principle, successful R\&D expenditure is classified as an intangible asset and had to be depreciated over 3 years on a straight line basis . M\&E and B\&S did not attract any special treatment and are depreciated over 4 years and 40 years, respectively (IBFD online database 2007). After the reform in 2005 'current' R\&D are expensed. CIT: 40.0\% (1991-1997), 36.0\% (1998), 34.0\% (1999), 28.0\% (2000-2002), 27.0\% (2003), 19.0\% (2004-2006).

Portugal. R\&D tax policy: From 1997 to 2000, current R\&D expenditure attracted a tax credit of $8 \%$ on the volume and $30 \%$ on incremental expenditure above the average expenditure in the previous 3 years (EC 2002) ${ }^{15}$ In June 2001 the credit was increased to $20 \%$ on volume and $50 \%$ on incremental expenditure (Decree law no. 197/2001). It understood that the base changed to a 2 year moving average (OECD 2002b). 2004 No scheme in place (OECD 2006). From 2004 expenditure attracts a tax credit $20 \%$ on volume and $50 \%$ on incremental expenditure (IBFD online database). Foreign contract R\&D: potentially eligible but R\&D must be at least 25 percent selffinanced. Depreciation: Depreciation schedule of 4 and 20 years (SL) for M\&E and B\&S, respectively is applied ${ }^{16}$ CIT: 23.0\% (1980-81), 40.0\% (19821986), 35.0\% (1987-88), 36.5\% (1989-90), 36.0\% (1991-1997), 37.0\% (1998),

\footnotetext{
${ }^{15}$ Decree law no. 292/97, and prolonged to cover 2001, 2002 and 2003 by Article 60 of Law no. 3-B/2000.

${ }^{16}$ Warda (1983) applies 3 years for M\&E however without knowing the exact year the laws were changed, or if this results from alternate interpretation of the same depreci-
} 
$34.0 \%$ (1999), 32.0\% (2000-01), 30.0\% (2002-03), 25.0\% (2004-06). WTD (2007) series show jumps in CIT to $39.6 \%$ in 1995 and 1997. These appear to be the sum of the $36 \%$ base tax rate and the $10 \%$ local surcharge. A rate of $36 \%$ is applied in these years.

Spain ${ }^{17}$ R\&D tax policy: $1981-8310 \%$ credit on all expenditure. Between 1984 and 1991, a credit of 15\%. 1992-95, 15\% credit on volume and $30 \%$ on incremental expenditure above a 2 year moving average. 1996-2000, $20 \%$ credit on volume and $40 \%$ on incremental expenditure Between 2001 and 2006, only current expenditure was eligible for the credit at a rate of $30 \%$ of volume and $50 \%$ on increment above the 3 year moving average. Foreign contract R\&D: no information about restrictions was identified. Depreciation: M\&E costs are expensed, B\&S 7 years SL 1980-1995, 10 years 1996 and 33 years 1997-2006. CIT: 33\% (1980-1983), 35\% (1984-2006).

Sweden. R\&D tax policy: 1980-1983 Special Deduction allowances of $10 \%$ on wage payments grossed up by two thirds. i.e. $16.7 \%$ total wage payments (McFetridge and Warda 1983). In addition, a $20 \%$ deduction was available on the increment on the previous year's expenditure (wages). Effective 1 Jan 1982, the base credit was reduced from $10 \%$ to $5 \%$ applied to $250 \%$ of wages, implying a $12.5 \%$ concession on wages (i.e., $112 \%$ of wage costs are deducted). With this change the incremental component was also increased to $30 \%$. No other special concession at other times. Foreign contract R\&D: no information about restrictions was identified. Depreciation: Depreciation rates 30\% DB for M\&E with B\&S over 25 years SL. CIT: 40.0\% (1980-1983), 32.0\% (1984), 52.0\% (1985-1989), 40.0\% (1990), 30.0\% (1991-1993), 28.0\% (1994-2006).

Switzerland. R\&D tax policy: Switzerland offered no special concession over the period covered by this study. Depreciation: Representative depreciation schedules applied are $40 \%$ and $8 \%$ (DB) for M\&E and B\&S respectively. CIT ${ }^{18} 30.2 \%$ (1980-1989), 28.5\% (1990-1997), 27.5\% (1998), 25.1\% (1999-2000), 24.7\% (2001), 24.5\% (2002), 24.1\% (2003-04), 21.3\% (2005-06). Foreign contract R\&D: no restrictions identified.

United Kingdom. R\&D tax policy: 1980-2000 no special concessions. From 2000, 125\% deduction on current expenditure is available for small companies with a turnover below 25m GBP (not modeled). From 1 April 2002 , a similar concession was introduced for large firms of $125 \%$ deduction

ation guidelines, to avoid erroneous temporal variation the same rate is applied across the whole time.

${ }^{17}$ Information for Spain was provided by J. Warda (personal communication).

${ }^{18}$ Switzerland CIT should consider the effect of the cantonal tax rate for Zurich. For 1993$2005, \mathrm{KMPG}$ data is used. KPMG report a jump of 5 p.p. to $29 \%$ for 2006 , however the OECD tax database series suggests no change between 2005 and 2006. Prior to 1993, the CIT is calculated based on the CG rate from WTD and adding the last known cantonal rate (18.5 p.p., inferred from the difference between WTD and KPMG and constant for the period 1993-1997). 
(IBFD 2007). Foreign contract R\&D: no restrictions. Depreciation: Both M\&E and B\&S are deducted in the year of expense. CIT: $52.0 \%(1980-1983)$, $50.0 \%$ (1984), 45.0\% (1985), 40.0\% (1986), 35.0\% (1987-1991), 33.0\% (19921997), 31.0\% (1998-1999), 30.0\% (2000-2006).

United States. R\&D tax policy: From 1981-1985 a 25\% tax credit was available on incremental expenditure. The base is defined as the average of the previous three years with a maximum allowable credit of $50 \%$ of total R\&D expenditure. In 1986, the credit is reduced to $20 \%$ of incremental expenditure. Until 1988, the credit itself was untaxed. In 1989 it was 50\% taxable and from 1990 onwards it is 100\% taxable. In 1990, the definition of the base expenditure was changed to reflect $R \& D$ to sales revenue over the period of 1984-88 (see Hall 1995; JCT 1997). We model this identically to a trailing 4 year moving average base, which is the case for a representative firm with constant $R \& D$ expenditure and constant real R\&D/sales ratio. Foreign contract $R \& D$ : no information about restrictions was identified. Depreciation: applied is 5 years SL for M\&E and for Buildings: 15yrs SL (1980-1984), 18yrs SL (1985), 19yrs SL (1986) and 39 years thereafter. The method for calculating depreciation was changed from 1987 with the introduction of the Modified Accelerated Cost Recovery System. CIT: $46.0 \%$ (1980-86), 40.0\% (1987), 34.0\% (1988-1992), 35.0\% (1993-2006). 


\section{References}

ABS (1990-2006). Research and Experimental Development, Business Canberra, Australian Bureau of Statistics. (Cat. 8104.0).

ATO 2002. R\&D Tax Concession Information Sheet - On own behalf Provisions. Canberra, Australian Taxation Office.

Athukorala, P. Kohpaiboon, A., 2010. Globalization of R\&D by US-based multinational enterprises. Research Policy 39, 1335-1347. doi:10.1016/j.respol.2010.09.004.

BIE 1993. Research Report 50. R\&D, Innovation and Competitiveness: An Evaluation of the Research and Development Tax Concession. Canberra, Bureau of Industry Economics.

Bloom, N., Griffith, R., van Reenen, J., 2002. Do R\&D Tax Credits Work? Evidence from a Panel of Countries 1979-1997. Journal of Public Economics 85, 1-31. doi:10.1016/S0047-2727(01)00086-X

Canadian Embassy Berlin 2003. A Summary of R\&D Tax Incentives in Canada.

DTT 2008. France Tax Alert: Private Letter Ruling Confirms Applicability of R\&D Tax Credit. Deloitte Touche Tohmatsu, France.

EC 2002. European Trend Chart on Innovation. Theme-specific Country Report: Portugal. http://cordis.europa.eu/en/home.html, European Commission, Community Research and Development Information Service

ETAN 1999a. An International Compendium of Indirect Schemes and Measures for Supporting Research and Technological Development in Enterprises, European Commission, European Technology Assessment Network. http:/ / www.cordis.lu/etan/src/topic-7.htm.

ETAN 1999b. An International Compendium of Indirect Schemes and Measures for Supporting Research and Technological Development in Enterprises. Supplementary Report, European Commission, European Technology Assessment Network. http://www.cordis.lu/etan/src/topic-7.htm.

Genser, B., 2001. Corporate Income Taxation in the European Union: Current State and Perspectives. Centre for Tax System Integrity Research School of Social Sciences Australian National University, Working Paper No 17.

Goolsbee, A., 1998. Does Government R\&D Policy Mainly Benefit Scientists and Engineers? American Economic Review 88, 298-302. 
Guellec, D., van Pottelsberghe, B., 2003. The Impact of Public R\&D Expenditure on Business R\&D. Economics of Innovation and New Technology 12, 225 - 243. doi:10.1080/10438590290004555

Hall, B.H., 1995. Effectiveness of Research and Experimentation Tax Credits: Critical Literature Review and Research Design. University of California Berkeley \& NBER.

IBFD 2004. Tax Treatment of Research \& Development Expenses. European Commission.

IBFD 2007. European Tax Surveys International Bureau of Fiscal Documentation. www.ibfd.org.

ICSTI 1998. Irish Council for Science Technology \& Innovation. Task Force Report 1998. http://www.forfas.ie/icsti/statements/innent/task.htm.

IRD 2000. Research \& Development Expenditure - Accounting Treatment for Tax Purposes. N. Z. Inland Revenue Department.

IRC 2005. Revenue Guidelines for Research and Development Tax Credit. The Irish Revenue Commisioners.

JCT 1997. The Blue Book, General Explanation of Tax Legislation Enacted in 1997. U.S. Joint Committee on Taxation.

Jorgenson, D.W., 1963. Capital Theory and Investment Behaviour. American Economic Review 53, 247-259.

Koga, T., 2003. Firm Size and R\&D Tax Incentives. Technovation 23, 643-648. doi:10.1016/S0166-4972(02)00010-X

KPMG 2007. KPMG Corporate Tax Rate Survey. KPMG.

Lattimore, R., 1997. Research and Development Fiscal Incentives in Australia: Impacts and Policy Lessons. In: Policy Evaluation in Innovation and Technology: Towards Best Practices. OECD, Paris, pp. 91-134, Chapter 8. Available at http://www.oecd.org/sti/inno/1907957.pdf

Lowtax.net 2008. Ireland Information: Business, Taxation and Offshore, http://www.lowtax.net/lowtax/html/jiroltr.html.

McAlpine, D., 2005. Tax Credits for R\&D Investment, PricewaterhousCoopers, London. Available at http://www.pwc.com/gx/eng/inssol/publ/ipvalue/Credits-RD-05.pdf.

McFetridge, D.G., Warda J.P., 1983. Canadian R\&D Incentives: Their Adequacy and Impact. Canadian Tax Paper No. 70. Canadian Tax Foundation, Toronto. 
Mulkay, B., Mairesse, J., 2003. The Effect of the R\&D Tax Credit in France. Unpublished manuscript.

NKTH 2006. Hungarian Tax Incentives for Research and Development National Office for Research and Technology Hungary.

OECD 1996. Fiscal Measures to Promote R\&D and Innovation. OECD, Paris.

OECD 1998. Technology, Productivity and Job Creation. Best Policy Practices. OECD, Paris.

OECD 2000. STI Outlook 2000: National Policies. Country Response, Korea. OECD, Paris.

OECD 2002a. Frascati Manual 2002: Proposed Standard Practice for Surveys on Research and Experimental Development. OECD, Paris.

OECD 2002b. Tax Incentives for Research and Development: Trends and Issues. OECD, Paris.

OECD 2005. Innovation Policy and Performance a Cross Country Comparison. OECD, Paris.

OECD 2006. OECD Science, Technology and Industry Outlook 2006. OECD, Paris.

OECD 2007. OECD Tax Database. OECD, Paris.

Rashkin, M.D., 2007. Practical Guide to Research and Development Tax Incentives. Federal, State and Foreign. Wolters Kluwer Business, Chicago.

Richardson, M., Wilkie, S., 1995. Incremental R\&D Subsidies. Journal of Regulatory Economics 7, 161-175. doi:10.1007/BF01062689

Sawyer, A.J., 2004. Potential Implications of Providing Tax Incentives for Research and Development in New Zealand. Department of Accountancy, Finance and Information Systems, University of Canterbury Christchurch.

Thomson, R., Jensen, P.H., 2013. The Effects of Public Subsidies on R\&D Employment: Evidence from OECD Countries. National Tax Journal 66, 281-310. doi:10.2139/ssrn.1740163

Thomson, R., 2013a. The Effect of R\&D Tax Credits: Cross Industry Evidence. Melbourne Institute Working Paper 18/13, The University of Melbourne.

Thomson, R., 2013b. National scientific capacity and R\&D offshoring. Research Policy 42, 517-528. doi:10.1016/j.respol.2012.07.003 
Wilson, D., 2009. Beggar Thy Neighbor? The In-State, Out-of-State, and Aggregate Effects of R\&D Tax Credits. Review of Economics and Statistics 91, 431-436. doi:10.1162/rest.91.2.431

Warda, J., 1996a. Measuring the Value of R\&D Tax Provisions. Fiscal Measures to Promote R\&D and Innovation. OECD, Paris.

Warda, J., 1996b. Background Paper for "Measuring the Value of R\&D Tax Provisions". Provided by the Author.

Warda, J., 1999. Measuring the Attractiveness of R\&D Tax Incentives: Canada and Major Industrial Countries. Statistics Canada, The Conference Board of Canada.

Warda, J., 2001. Measuring the Value of R\&D Tax Treatment in OECD Countries. Science and Technology Review 27, 185-211. OECD, Paris.

Warda, J., 2003. Extending Access to SR\&ED Tax Credits: An International Comparitive Analysis. Information Technology Association of Canada 22.

Warda, J., 2006. Tax Treatment of Business Investments in Intellectual Assets: An International Comparison. STI Working Paper 2006/4. OECD, Paris.

WTD 2007. World Tax Database, University of Michigan.

Wolff, G., Reinthaler, W., 2008. The Effectiveness of Subsidies Revisited: Accounting for Wage and Employment Effects in Business R\&D. Research Policy 37, 1403-1412. doi:10.1016/j.respol.2008.04.023 
Table A1 - Dataset

\begin{tabular}{|c|c|c|c|c|c|c|c|}
\hline Country & Year & CIT & Labour & Oth. Curr. & M\&E & B\&S & Foreign \\
\hline Australia & 1980 & 0.46 & 1 & 1 & 1.075 & 1.075 & 1.008 \\
\hline Australia & 1981 & 0.46 & 1 & 1 & 1.075 & 1.075 & 1.008 \\
\hline Australia & 1982 & 0.46 & 1 & 1 & 1.075 & 1.075 & 1.008 \\
\hline Australia & 1983 & 0.46 & 1 & 1 & 1.075 & 1.075 & 1.008 \\
\hline Australia & 1984 & 0.46 & 1 & 1 & 1.075 & 1.075 & 1.008 \\
\hline Australia & 1985 & 0.46 & 0.574 & 0.574 & 0.687 & 0.687 & 1.008 \\
\hline Australia & 1986 & 0.46 & 0.574 & 0.574 & 0.687 & 1.623 & 1.008 \\
\hline Australia & 1987 & 0.49 & 0.52 & 0.52 & 0.647 & 1.702 & 1.039 \\
\hline Australia & 1988 & 0.49 & 0.52 & 0.52 & 0.647 & 1.702 & 1.039 \\
\hline Australia & 1989 & 0.39 & 0.68 & 0.68 & 0.765 & 1.467 & 1.026 \\
\hline Australia & 1990 & 0.39 & 0.68 & 0.68 & 0.765 & 1.467 & 1.026 \\
\hline Australia & 1991 & 0.39 & 0.68 & 0.68 & 0.765 & 1.467 & 1.026 \\
\hline Australia & 1992 & 0.39 & 0.68 & 0.68 & 0.765 & 1.467 & 1.026 \\
\hline Australia & 1993 & 0.39 & 0.68 & 0.68 & 0.765 & 1.467 & 1.026 \\
\hline Australia & 1994 & 0.33 & 0.754 & 0.754 & 0.819 & 1.36 & 1.02 \\
\hline Australia & 1995 & 0.33 & 0.754 & 0.754 & 0.819 & 1.36 & 1.02 \\
\hline Australia & 1996 & 0.36 & 0.859 & 0.859 & 0.921 & 1.411 & 1.023 \\
\hline Australia & 1997 & 0.36 & 0.859 & 0.859 & 0.976 & 1.411 & 1.025 \\
\hline Australia & 1998 & 0.36 & 0.859 & 0.859 & 0.976 & 1.411 & 1.025 \\
\hline Australia & 1999 & 0.36 & 0.859 & 0.859 & 0.976 & 1.411 & 1.025 \\
\hline Australia & 2000 & 0.34 & 0.871 & 0.871 & 0.978 & 1.377 & 1.023 \\
\hline Australia & 2001 & 0.3 & 0.856 & 0.856 & 0.951 & 1.313 & 1.019 \\
\hline Australia & 2002 & 0.3 & 0.856 & 0.856 & 0.951 & 1.313 & 1.019 \\
\hline Australia & 2003 & 0.3 & 0.856 & 0.856 & 0.951 & 1.313 & 1.019 \\
\hline Australia & 2004 & 0.3 & 0.856 & 0.856 & 0.951 & 1.313 & 1.019 \\
\hline Australia & 2005 & 0.3 & 0.856 & 0.856 & 0.951 & 1.313 & 1.019 \\
\hline Australia & 2006 & 0.3 & 0.856 & 0.856 & 0.951 & 1.313 & 1.019 \\
\hline Austria & 1980 & 0.55 & 0.939 & 0.939 & 1.051 & 1.051 & 0.95 \\
\hline Austria & 1981 & 0.55 & 0.939 & 0.939 & 1.051 & 1.051 & 0.95 \\
\hline Austria & 1982 & 0.55 & 0.939 & 0.939 & 1.051 & 1.051 & 0.95 \\
\hline Austria & 1983 & 0.55 & 0.939 & 0.939 & 1.051 & 1.051 & 0.95 \\
\hline Austria & 1984 & 0.55 & 0.939 & 0.939 & 1.203 & 1.734 & 0.992 \\
\hline Austria & 1985 & 0.55 & 0.939 & 0.939 & 1.203 & 1.734 & 0.992 \\
\hline Austria & 1986 & 0.55 & 0.939 & 0.939 & 1.203 & 1.734 & 0.992 \\
\hline Austria & 1987 & 0.55 & 0.939 & 0.939 & 1.203 & 1.734 & 0.992 \\
\hline Austria & 1988 & 0.55 & 0.939 & 0.939 & 1.203 & 1.734 & 0.992 \\
\hline Austria & 1989 & 0.3 & 0.923 & 0.923 & 1.071 & 1.257 & 0.997 \\
\hline Austria & 1990 & 0.3 & 0.923 & 0.923 & 1.071 & 1.257 & 0.997 \\
\hline Austria & 1991 & 0.3 & 0.923 & 0.923 & 1.071 & 1.257 & 0.997 \\
\hline Austria & 1992 & 0.3 & 0.923 & 0.923 & 1.039 & 1.242 & 0.943 \\
\hline Austria & 1993 & 0.3 & 0.923 & 0.923 & 1.039 & 1.242 & 0.943 \\
\hline Austria & 1994 & 0.34 & 0.907 & 0.907 & 1.047 & 1.291 & 0.932 \\
\hline Austria & 1995 & 0.34 & 0.907 & 0.907 & 1.047 & 1.291 & 0.932 \\
\hline Austria & 1996 & 0.34 & 0.907 & 0.907 & 1.047 & 1.291 & 0.932 \\
\hline Austria & 1997 & 0.34 & 0.907 & 0.907 & 1.047 & 1.291 & 0.932 \\
\hline Austria & 1998 & 0.34 & 0.907 & 0.907 & 1.047 & 1.291 & 0.932 \\
\hline Austria & 1999 & 0.34 & 0.907 & 0.907 & 1.047 & 1.291 & 0.932 \\
\hline Austria & 2000 & 0.34 & 0.862 & 0.862 & 1.047 & 1.291 & 0.891 \\
\hline
\end{tabular}

(To be continued) 
Table A1 - Dataset (continued)

\begin{tabular}{|c|c|c|c|c|c|c|c|}
\hline Country & Year & CIT & Labour & Oth. Curr. & M\&E & B\&S & Foreign \\
\hline Austria & 2001 & 0.34 & 0.862 & 0.862 & 1.047 & 1.291 & 0.891 \\
\hline Austria & 2002 & 0.34 & 0.862 & 0.862 & 1.047 & 1.291 & 0.891 \\
\hline Austria & 2003 & 0.34 & 0.862 & 0.862 & 1.021 & 1.279 & 0.888 \\
\hline Austria & 2004 & 0.34 & 0.862 & 0.862 & 1.021 & 1.279 & 0.888 \\
\hline Austria & 2005 & 0.25 & 0.893 & 0.893 & 1.055 & 1.2 & 0.917 \\
\hline Austria & 2006 & 0.25 & 0.893 & 0.893 & 1.055 & 1.2 & 0.917 \\
\hline Belgium & 1980 & 0.48 & 0.956 & 0.956 & 0.957 & 1.47 & 0.982 \\
\hline Belgium & 1981 & 0.48 & 1 & 1 & 0.997 & 1.491 & 1.024 \\
\hline Belgium & 1982 & 0.48 & 1 & 1 & 0.997 & 1.491 & 1.024 \\
\hline Belgium & 1983 & 0.45 & 1 & 1 & 0.998 & 1.435 & 1.021 \\
\hline Belgium & 1984 & 0.45 & 1 & 1 & 0.998 & 1.435 & 1.021 \\
\hline Belgium & 1985 & 0.45 & 1 & 1 & 0.998 & 1.435 & 1.021 \\
\hline Belgium & 1986 & 0.45 & 1 & 1 & 0.998 & 1.435 & 1.021 \\
\hline Belgium & 1987 & 0.43 & 1 & 1 & 0.998 & 1.401 & 1.02 \\
\hline Belgium & 1988 & 0.43 & 1 & 1 & 0.998 & 1.401 & 1.02 \\
\hline Belgium & 1989 & 0.43 & 1 & 1 & 0.998 & 1.401 & 1.02 \\
\hline Belgium & 1990 & 0.41 & 1 & 1 & 0.976 & 1.326 & 1.012 \\
\hline Belgium & 1991 & 0.39 & 1 & 1 & 0.978 & 1.3 & 1.011 \\
\hline Belgium & 1992 & 0.39 & 1 & 1 & 0.978 & 1.3 & 1.011 \\
\hline Belgium & 1993 & 0.39 & 1 & 1 & 0.978 & 1.3 & 1.011 \\
\hline Belgium & 1994 & 0.39 & 1 & 1 & 0.978 & 1.3 & 1.011 \\
\hline Belgium & 1995 & 0.39 & 1 & 1 & 0.978 & 1.3 & 1.011 \\
\hline Belgium & 1996 & 0.39 & 1 & 1 & 0.978 & 1.3 & 1.011 \\
\hline Belgium & 1997 & 0.39 & 1 & 1 & 0.978 & 1.3 & 1.011 \\
\hline Belgium & 1998 & 0.39 & 1 & 1 & 0.978 & 1.3 & 1.011 \\
\hline Belgium & 1999 & 0.39 & 1 & 1 & 0.978 & 1.3 & 1.011 \\
\hline Belgium & 2000 & 0.39 & 1 & 1 & 0.978 & 1.3 & 1.011 \\
\hline Belgium & 2001 & 0.39 & 1 & 1 & 0.978 & 1.3 & 1.011 \\
\hline Belgium & 2002 & 0.39 & 1 & 1 & 0.978 & 1.3 & 1.011 \\
\hline Belgium & 2003 & 0.33 & 1 & 1 & 0.983 & 1.231 & 1.009 \\
\hline Belgium & 2004 & 0.33 & 1 & 1 & 0.983 & 1.231 & 1.009 \\
\hline Belgium & 2005 & 0.33 & 1 & 1 & 0.983 & 1.231 & 1.009 \\
\hline Belgium & 2006 & 0.33 & 1 & 1 & 0.983 & 1.231 & 1.009 \\
\hline Canada & 1980 & 0.46 & 0.832 & 0.832 & 0.832 & 0.832 & 0.832 \\
\hline Canada & 1981 & 0.46 & 0.832 & 0.832 & 0.832 & 0.832 & 0.832 \\
\hline Canada & 1982 & 0.46 & 0.832 & 0.832 & 0.832 & 0.832 & 0.832 \\
\hline Canada & 1983 & 0.46 & 0.8 & 0.8 & 0.8 & 1 & 0.81 \\
\hline Canada & 1984 & 0.46 & 0.8 & 0.8 & 0.8 & 1 & 0.81 \\
\hline Canada & 1985 & 0.46 & 0.8 & 0.8 & 0.8 & 1 & 0.81 \\
\hline Canada & 1986 & 0.46 & 0.8 & 0.8 & 0.8 & 1 & 0.81 \\
\hline Canada & 1987 & 0.46 & 0.8 & 0.8 & 0.8 & 1 & 0.81 \\
\hline Canada & 1988 & 0.42 & 0.8 & 0.8 & 0.8 & 1.486 & 0.834 \\
\hline Canada & 1989 & 0.38 & 0.8 & 0.8 & 0.8 & 1.42 & 0.831 \\
\hline Canada & 1990 & 0.38 & 0.8 & 0.8 & 0.8 & 1.42 & 0.831 \\
\hline Canada & 1991 & 0.38 & 0.8 & 0.8 & 0.8 & 1.42 & 0.831 \\
\hline Canada & 1992 & 0.38 & 0.8 & 0.8 & 0.8 & 1.42 & 0.831 \\
\hline Canada & 1993 & 0.38 & 0.8 & 0.8 & 0.8 & 1.42 & 0.831 \\
\hline Canada & 1994 & 0.38 & 0.8 & 0.8 & 0.8 & 1.42 & 0.831 \\
\hline
\end{tabular}

(To be continued) 
Table A1 - Dataset (continued)

\begin{tabular}{|c|c|c|c|c|c|c|c|}
\hline Country & Year & CIT & Labour & Oth. Curr. & M\&E & B\&S & Foreign \\
\hline Canada & 1995 & 0.38 & 0.8 & 0.8 & 0.8 & 1.42 & 0.831 \\
\hline Canada & 1996 & 0.38 & 0.8 & 0.8 & 0.8 & 1.42 & 0.831 \\
\hline Canada & 1997 & 0.38 & 0.8 & 0.8 & 0.8 & 1.42 & 0.831 \\
\hline Canada & 1998 & 0.38 & 0.8 & 0.8 & 0.8 & 1.42 & 0.831 \\
\hline Canada & 1999 & 0.38 & 0.8 & 0.8 & 0.8 & 1.42 & 0.831 \\
\hline Canada & 2000 & 0.38 & 0.8 & 0.8 & 0.8 & 1.42 & 0.831 \\
\hline Canada & 2001 & 0.38 & 0.8 & 0.8 & 0.8 & 1.42 & 0.831 \\
\hline Canada & 2002 & 0.38 & 0.8 & 0.8 & 0.8 & 1.42 & 0.831 \\
\hline Canada & 2003 & 0.33 & 0.8 & 0.8 & 0.8 & 1.338 & 0.827 \\
\hline Canada & 2004 & 0.31 & 0.8 & 0.8 & 0.8 & 1.308 & 0.825 \\
\hline Canada & 2005 & 0.31 & 0.8 & 0.8 & 0.8 & 1.308 & 0.825 \\
\hline Canada & 2006 & 0.31 & 0.8 & 0.8 & 0.8 & 1.308 & 0.825 \\
\hline Czech Republic & 1980 & & - & - & - & - & - \\
\hline Czech Republic & 1981 & - & - & - & - & - & - \\
\hline Czech Republic & 1982 & - & - & - & - & - & - \\
\hline Czech Republic & 1983 & - & - & - & - & - & - \\
\hline Czech Republic & 1984 & - & - & - & - & - & - \\
\hline Czech Republic & 1985 & - & - & - & - & - & - \\
\hline Czech Republic & 1986 & - & - & - & - & - & - \\
\hline Czech Republic & 1987 & - & - & - & - & - & - \\
\hline Czech Republic & 1988 & - & - & - & - & - & - \\
\hline Czech Republic & 1989 & - & - & - & - & - & - \\
\hline Czech Republic & 1990 & - & - & - & - & - & - \\
\hline Czech Republic & 1991 & - & - & - & - & - & - \\
\hline Czech Republic & 1992 & 0.4 & 1 & 1 & 1.111 & 1.436 & 1.027 \\
\hline Czech Republic & 1993 & 0.45 & 1 & 1 & 1.136 & 1.535 & 1.034 \\
\hline Czech Republic & 1994 & 0.42 & 1 & 1 & 1.12 & 1.474 & 1.03 \\
\hline Czech Republic & 1995 & 0.41 & 1 & 1 & 1.115 & 1.455 & 1.029 \\
\hline Czech Republic & 1996 & 0.39 & 1 & 1 & 1.106 & 1.418 & 1.026 \\
\hline Czech Republic & 1997 & 0.39 & 1 & 1 & 1.106 & 1.418 & 1.026 \\
\hline Czech Republic & 1998 & 0.35 & 1 & 1 & 1.089 & 1.352 & 1.022 \\
\hline Czech Republic & 1999 & 0.35 & 1 & 1 & 1.089 & 1.352 & 1.022 \\
\hline Czech Republic & 2000 & 0.35 & 1 & 1 & 1.089 & 1.352 & 1.022 \\
\hline Czech Republic & 2001 & 0.31 & 1 & 1 & 1.075 & 1.294 & 1.018 \\
\hline Czech Republic & 2002 & 0.31 & 1 & 1 & 1.075 & 1.294 & 1.018 \\
\hline Czech Republic & 2003 & 0.31 & 1 & 1 & 1.075 & 1.294 & 1.018 \\
\hline Czech Republic & 2004 & 0.28 & 1 & 1 & 1.065 & 1.254 & 1.016 \\
\hline Czech Republic & 2005 & 0.26 & 0.649 & 0.649 & 1.058 & 1.23 & 0.698 \\
\hline Czech Republic & 2006 & 0.24 & 0.684 & 0.684 & 1.052 & 1.207 & 0.729 \\
\hline Denmark & 1980 & 0.4 & 1 & 1 & 1 & 1 & 1 \\
\hline Denmark & 1981 & 0.4 & 1 & 1 & 1 & 1 & 1 \\
\hline
\end{tabular}

(To be continued) 
Table A1 - Dataset (continued)

\begin{tabular}{|c|c|c|c|c|c|c|c|}
\hline Country & Year & CIT & Labour & Oth. Curr. & M\&E & B\&S & Foreign \\
\hline Denmark & 1982 & 0.4 & 1 & 1 & 1 & 1 & 1 \\
\hline Denmark & 1983 & 0.4 & 1 & 1 & 1 & 1 & 1 \\
\hline Denmark & 1984 & 0.4 & 1 & 1 & 1 & 1 & 1 \\
\hline Denmark & 1985 & 0.4 & 1 & 1 & 1 & 1 & 1 \\
\hline Denmark & 1986 & 0.5 & 1 & 1 & 1 & 1 & 1 \\
\hline Denmark & 1987 & 0.5 & 1 & 1 & 1 & 1 & 1 \\
\hline Denmark & 1988 & 0.5 & 1 & 1 & 1 & 1 & 1 \\
\hline Denmark & 1989 & 0.5 & 1 & 1 & 1 & 1 & 1 \\
\hline Denmark & 1990 & 0.4 & 1 & 1 & 1 & 1 & 1 \\
\hline Denmark & 1991 & 0.38 & 1 & 1 & 1 & 1 & 1 \\
\hline Denmark & 1992 & 0.38 & 1 & 1 & 1 & 1 & 1 \\
\hline Denmark & 1993 & 0.34 & 1 & 1 & 1 & 1 & 1 \\
\hline Denmark & 1994 & 0.34 & 1 & 1 & 1 & 1 & 1 \\
\hline Denmark & 1995 & 0.34 & 1 & 1 & 1 & 1 & 1 \\
\hline Denmark & 1996 & 0.34 & 1 & 1 & 1 & 1 & 1 \\
\hline Denmark & 1997 & 0.34 & 1 & 1 & 1 & 1 & 1 \\
\hline Denmark & 1998 & 0.34 & 1 & 1 & 1.09 & 1.274 & 1.018 \\
\hline Denmark & 1999 & 0.32 & 1 & 1 & 1.082 & 1.25 & 1.017 \\
\hline Denmark & 2000 & 0.32 & 1 & 1 & 1.082 & 1.25 & 1.017 \\
\hline Denmark & 2001 & 0.3 & 1 & 1 & 1.075 & 1.228 & 1.015 \\
\hline Denmark & 2002 & 0.3 & 1 & 1 & 1.075 & 1.228 & 1.015 \\
\hline Denmark & 2003 & 0.3 & 1 & 1 & 1.075 & 1.228 & 1.015 \\
\hline Denmark & 2004 & 0.3 & 1 & 1 & 1.075 & 1.228 & 1.015 \\
\hline Denmark & 2005 & 0.28 & 1 & 1 & 1.068 & 1.207 & 1.014 \\
\hline Denmark & 2006 & 0.28 & 1 & 1 & 1.068 & 1.207 & 1.014 \\
\hline Finland & 1980 & 0.43 & 1 & 1 & 1.162 & 1.201 & 1.018 \\
\hline Finland & 1981 & 0.43 & 1 & 1 & 1.162 & 1.201 & 1.018 \\
\hline Finland & 1982 & 0.43 & 1 & 1 & 1.162 & 1.201 & 1.018 \\
\hline Finland & 1983 & 0.43 & 0.897 & 0.897 & 1.162 & 1.201 & 0.926 \\
\hline Finland & 1984 & 0.43 & 0.897 & 0.897 & 1.162 & 1.201 & 0.926 \\
\hline Finland & 1985 & 0.43 & 0.897 & 0.897 & 1.162 & 1.201 & 0.926 \\
\hline Finland & 1986 & 0.33 & 0.933 & 0.933 & 1.106 & 1.131 & 0.951 \\
\hline Finland & 1987 & 0.33 & 0.933 & 0.933 & 1.106 & 1.131 & 0.951 \\
\hline Finland & 1988 & 0.33 & 1 & 1 & 1.106 & 1.131 & 1.012 \\
\hline Finland & 1989 & 0.33 & 1 & 1 & 1.106 & 1.131 & 1.012 \\
\hline Finland & 1990 & 0.25 & 1 & 1 & 1.071 & 1.089 & 1.008 \\
\hline Finland & 1991 & 0.23 & 1 & 1 & 1.064 & 1.08 & 1.007 \\
\hline Finland & 1992 & 0.19 & 1 & 1 & 1.05 & 1.063 & 1.006 \\
\hline Finland & 1993 & 0.25 & 1 & 1 & 1.071 & 1.089 & 1.008 \\
\hline Finland & 1994 & 0.25 & 1 & 1 & 1.071 & 1.089 & 1.008 \\
\hline Finland & 1995 & 0.25 & 1 & 1 & 1.071 & 1.089 & 1.008 \\
\hline Finland & 1996 & 0.28 & 1 & 1 & 1.083 & 1.104 & 1.009 \\
\hline Finland & 1997 & 0.28 & 1 & 1 & 1.083 & 1.104 & 1.009 \\
\hline Finland & 1998 & 0.28 & 1 & 1 & 1.083 & 1.104 & 1.009 \\
\hline Finland & 1999 & 0.28 & 1 & 1 & 1.083 & 1.104 & 1.009 \\
\hline Finland & 2000 & 0.29 & 1 & 1 & 1.088 & 1.109 & 1.01 \\
\hline Finland & 2001 & 0.29 & 1 & 1 & 1.088 & 1.109 & 1.01 \\
\hline Finland & 2002 & 0.29 & 1 & 1 & 1.088 & 1.109 & 1.01 \\
\hline
\end{tabular}

(To be continued) 
Table A1 - Dataset (continued)

\begin{tabular}{|c|c|c|c|c|c|c|c|}
\hline Country & Year & CIT & Labour & Oth. Curr. & M\&E & B\&S & Foreign \\
\hline Finland & 2003 & 0.29 & 1 & 1 & 1.088 & 1.109 & 1.01 \\
\hline Finland & 2004 & 0.29 & 1 & 1 & 1.088 & 1.109 & 1.01 \\
\hline Finland & 2005 & 0.26 & 1 & 1 & 1.075 & 1.094 & 1.008 \\
\hline Finland & 2006 & 0.26 & 1 & 1 & 1.075 & 1.094 & 1.008 \\
\hline France & 1980 & 0.5 & 1 & 1 & 1.12 & 1.532 & 1.033 \\
\hline France & 1981 & 0.5 & 1 & 1 & 1.12 & 1.532 & 1.033 \\
\hline France & 1982 & 0.5 & 1 & 1 & 1.12 & 1.532 & 1.033 \\
\hline France & 1983 & 0.5 & 0.955 & 0.955 & 1.075 & 1.266 & 0.976 \\
\hline France & 1984 & 0.5 & 0.955 & 0.955 & 1.075 & 1.266 & 0.976 \\
\hline France & 1985 & 0.5 & 0.909 & 0.909 & 1.029 & 1.266 & 0.933 \\
\hline France & 1986 & 0.5 & 0.909 & 0.909 & 1.029 & 1.266 & 0.933 \\
\hline France & 1987 & 0.45 & 0.917 & 0.917 & 1.016 & 1.435 & 0.948 \\
\hline France & 1988 & 0.42 & 0.922 & 0.922 & 1.009 & 1.385 & 0.949 \\
\hline France & 1989 & 0.39 & 0.915 & 0.915 & 0.991 & 1.34 & 0.94 \\
\hline France & 1990 & 0.37 & 0.882 & 0.882 & 0.952 & 1.312 & 0.907 \\
\hline France & 1991 & 0.34 & 0.9 & 0.9 & 0.962 & 1.274 & 0.922 \\
\hline France & 1992 & 0.34 & 0.9 & 0.9 & 0.962 & 1.274 & 0.922 \\
\hline France & 1993 & 0.33 & 0.901 & 0.901 & 0.961 & 1.265 & 0.922 \\
\hline France & 1994 & 0.33 & 0.901 & 0.901 & 0.961 & 1.265 & 0.922 \\
\hline France & 1995 & 0.33 & 0.901 & 0.901 & 0.961 & 1.265 & 0.922 \\
\hline France & 1996 & 0.33 & 0.901 & 0.901 & 0.961 & 1.265 & 0.922 \\
\hline France & 1997 & 0.33 & 0.901 & 0.901 & 0.961 & 1.265 & 0.922 \\
\hline France & 1998 & 0.33 & 0.901 & 0.901 & 0.961 & 1.265 & 0.922 \\
\hline France & 1999 & 0.33 & 0.901 & 0.901 & 0.961 & 1.265 & 0.922 \\
\hline France & 2000 & 0.33 & 0.901 & 0.901 & 0.961 & 1.265 & 0.922 \\
\hline France & 2001 & 0.33 & 0.901 & 0.901 & 0.961 & 1.265 & 0.922 \\
\hline France & 2002 & 0.33 & 0.901 & 0.901 & 0.961 & 1.265 & 0.922 \\
\hline France & 2003 & 0.33 & 0.901 & 0.901 & 0.961 & 1.266 & 0.922 \\
\hline France & 2004 & 0.33 & 0.846 & 0.846 & 0.906 & 1.112 & 0.862 \\
\hline France & 2005 & 0.33 & 0.846 & 0.846 & 0.906 & 1.111 & 0.862 \\
\hline France & 2006 & 0.34 & 0.787 & 0.787 & 0.85 & 1.066 & 0.804 \\
\hline Germany & 1980 & 0.62 & 1 & 1 & 1.283 & 2.109 & 1.07 \\
\hline Germany & 1981 & 0.62 & 1 & 1 & 1.283 & 2.109 & 1.07 \\
\hline Germany & 1982 & 0.62 & 1 & 1 & 1.283 & 2.109 & 1.07 \\
\hline Germany & 1983 & 0.62 & 1 & 1 & 1.283 & 2.109 & 1.07 \\
\hline Germany & 1984 & 0.62 & 1 & 1 & 1.283 & 2.109 & 1.07 \\
\hline Germany & 1985 & 0.62 & 1 & 1 & 1.283 & 2.109 & 1.07 \\
\hline Germany & 1986 & 0.62 & 1 & 1 & 1.283 & 2.109 & 1.07 \\
\hline Germany & 1987 & 0.62 & 1 & 1 & 1.283 & 2.109 & 1.07 \\
\hline Germany & 1988 & 0.62 & 1 & 1 & 1.283 & 2.109 & 1.07 \\
\hline Germany & 1989 & 0.62 & 1 & 1 & 1.283 & 2.109 & 1.07 \\
\hline Germany & 1990 & 0.58 & 1 & 1 & 1.244 & 1.955 & 1.06 \\
\hline Germany & 1991 & 0.57 & 1 & 1 & 1.228 & 1.894 & 1.056 \\
\hline Germany & 1992 & 0.57 & 1 & 1 & 1.228 & 1.894 & 1.056 \\
\hline Germany & 1993 & 0.6 & 1 & 1 & 1.259 & 2.015 & 1.064 \\
\hline Germany & 1994 & 0.56 & 1 & 1 & 1.219 & 1.86 & 1.054 \\
\hline Germany & 1995 & 0.59 & 1 & 1 & 1.252 & 1.987 & 1.062 \\
\hline Germany & 1996 & 0.59 & 1 & 1 & 1.252 & 1.987 & 1.062 \\
\hline
\end{tabular}

(To be continued) 
Table A1 - Dataset (continued)

\begin{tabular}{|c|c|c|c|c|c|c|c|}
\hline Country & Year & CIT & Labour & Oth. Curr. & M\&E & B\&S & Foreign \\
\hline Germany & 1997 & 0.58 & 1 & 1 & 1.237 & 1.928 & 1.058 \\
\hline Germany & 1998 & 0.57 & 1 & 1 & 1.232 & 1.909 & 1.057 \\
\hline Germany & 1999 & 0.52 & 1 & 1 & 1.19 & 1.743 & 1.047 \\
\hline Germany & 2000 & 0.52 & 1 & 1 & 1.19 & 1.743 & 1.047 \\
\hline Germany & 2001 & 0.38 & 1 & 1 & 1.107 & 1.42 & 1.026 \\
\hline Germany & 2002 & 0.38 & 1 & 1 & 1.107 & 1.42 & 1.026 \\
\hline Germany & 2003 & 0.4 & 1 & 1 & 1.117 & 1.457 & 1.029 \\
\hline Germany & 2004 & 0.38 & 1 & 1 & 1.107 & 1.42 & 1.026 \\
\hline Germany & 2005 & 0.38 & 1 & 1 & 1.163 & 1.417 & 1.029 \\
\hline Germany & 2006 & 0.38 & 1 & 1 & 1.166 & 1.423 & 1.029 \\
\hline Greece & 1980 & 0.43 & 1 & 1 & 1.068 & 1.297 & 1.018 \\
\hline Greece & 1981 & 0.43 & 1 & 1 & 1 & 1.297 & 1.015 \\
\hline Greece & 1982 & 0.43 & 1 & 1 & 1 & 1.297 & 1.015 \\
\hline Greece & 1983 & 0.49 & 1 & 1 & 1 & 1.365 & 1.018 \\
\hline Greece & 1984 & 0.49 & 1 & 1 & 1 & 1.365 & 1.018 \\
\hline Greece & 1985 & 0.49 & 1 & 1 & 1 & 1.372 & 1.019 \\
\hline Greece & 1986 & 0.49 & 1 & 1 & 1 & 1.372 & 1.019 \\
\hline Greece & 1987 & 0.49 & 1 & 1 & 1 & 1.372 & 1.019 \\
\hline Greece & 1988 & 0.49 & 1 & 1 & 1 & 1.372 & 1.019 \\
\hline Greece & 1989 & 0.46 & 1 & 1 & 1 & 1.33 & 1.016 \\
\hline Greece & 1990 & 0.46 & 1 & 1 & 1 & 1.33 & 1.016 \\
\hline Greece & 1991 & 0.46 & 1 & 1 & 1 & 1.33 & 1.016 \\
\hline Greece & 1992 & 0.46 & 1 & 1 & 1 & 1.33 & 1.016 \\
\hline Greece & 1993 & 0.35 & 1 & 1 & 1 & 1.209 & 1.01 \\
\hline Greece & 1994 & 0.35 & 1 & 1 & 1 & 1.209 & 1.01 \\
\hline Greece & 1995 & 0.35 & 1 & 1 & 1 & 1.209 & 1.01 \\
\hline Greece & 1996 & 0.35 & 1 & 1 & 1 & 1.209 & 1.01 \\
\hline Greece & 1997 & 0.35 & 1 & 1 & 1 & 1.209 & 1.01 \\
\hline Greece & 1998 & 0.35 & 1 & 1 & 1 & 1.209 & 1.01 \\
\hline Greece & 1999 & 0.35 & 1 & 1 & 1.047 & 1.209 & 1.013 \\
\hline Greece & 2000 & 0.35 & 1 & 1 & 1.047 & 1.209 & 1.013 \\
\hline Greece & 2001 & 0.35 & 1 & 1 & 1.047 & 1.209 & 1.013 \\
\hline Greece & 2002 & 0.35 & 1 & 1 & 1.047 & 1.209 & 1.013 \\
\hline Greece & 2003 & 0.35 & 1 & 1 & 1.047 & 1.209 & 1.013 \\
\hline Greece & 2004 & 0.35 & 1 & 1 & 1.047 & 1.209 & 1.013 \\
\hline Greece & 2005 & 0.32 & 1 & 1 & 1.041 & 1.182 & 1.011 \\
\hline Greece & 2006 & 0.29 & 1 & 1 & 1.036 & 1.158 & 1.01 \\
\hline Hungary & 1980 & - & - & - & - & - & - \\
\hline Hungary & 1981 & - & - & - & - & - & - \\
\hline Hungary & 1982 & - & - & - & - & - & - \\
\hline Hungary & 1983 & - & - & - & - & - & - \\
\hline Hungary & 1984 & - & - & - & - & - & - \\
\hline Hungary & 1985 & - & - & - & - & - & - \\
\hline Hungary & 1986 & - & - & - & - & - & - \\
\hline Hungary & 1987 & - & - & - & - & - & - \\
\hline Hungary & 1988 & - & - & - & - & - & - \\
\hline Hungary & 1989 & - & - & - & - & - & - \\
\hline Hungary & 1990 & 0.4 & 1 & 1 & 1.059 & 1.521 & 1.029 \\
\hline
\end{tabular}

(To be continued) 
Table A1 - Dataset (continued)

\begin{tabular}{|c|c|c|c|c|c|c|c|}
\hline Country & Year & CIT & Labour & Oth. Curr. & M\&E & B\&S & Foreign \\
\hline Hungary & 1991 & 0.4 & 1 & 1 & 1.059 & 1.521 & 1.029 \\
\hline Hungary & 1992 & 0.4 & 1 & 1 & 1.059 & 1.521 & 1.029 \\
\hline Hungary & 1993 & 0.4 & 1 & 1 & 1.059 & 1.521 & 1.029 \\
\hline Hungary & 1994 & 0.36 & 1 & 1 & 1.05 & 1.44 & 1.024 \\
\hline Hungary & 1995 & 0.18 & 1 & 1 & 1.019 & 1.172 & 1.01 \\
\hline Hungary & 1996 & 0.18 & 1 & 1 & 1.019 & 1.172 & 1.01 \\
\hline Hungary & 1997 & 0.18 & 0.956 & 0.956 & 1.019 & 1.172 & 0.97 \\
\hline Hungary & 1998 & 0.18 & 0.956 & 0.956 & 1.019 & 1.172 & 0.97 \\
\hline Hungary & 1999 & 0.18 & 0.956 & 0.956 & 1.019 & 1.172 & 0.97 \\
\hline Hungary & 2000 & 0.18 & 0.78 & 0.78 & 1.019 & 1.172 & 0.812 \\
\hline Hungary & 2001 & 0.18 & 0.78 & 0.78 & 1.019 & 1.172 & 0.812 \\
\hline Hungary & 2002 & 0.18 & 0.78 & 0.78 & 1.019 & 1.172 & 0.812 \\
\hline Hungary & 2003 & 0.18 & 0.78 & 0.78 & 1.019 & 1.172 & 0.812 \\
\hline Hungary & 2004 & 0.16 & 0.81 & 0.81 & 1.017 & 1.149 & 0.837 \\
\hline Hungary & 2005 & 0.16 & 0.81 & 0.81 & 1.017 & 1.149 & 0.837 \\
\hline Hungary & 2006 & 0.16 & 0.81 & 0.81 & 1.017 & 1.149 & 0.837 \\
\hline Ireland & 1980 & 0.45 & 1 & 1 & 1 & 1 & 1 \\
\hline Ireland & 1981 & 0.1 & 1 & 1 & 1 & 1 & 1 \\
\hline Ireland & 1982 & 0.1 & 1 & 1 & 1 & 1 & 1 \\
\hline Ireland & 1983 & 0.1 & 1 & 1 & 1 & 1 & 1 \\
\hline Ireland & 1984 & 0.1 & 1 & 1 & 1 & 1 & 1 \\
\hline Ireland & 1985 & 0.1 & 1 & 1 & 1 & 1 & 1 \\
\hline Ireland & 1986 & 0.1 & 1 & 1 & 1 & 1 & 1 \\
\hline Ireland & 1987 & 0.1 & 1 & 1 & 1 & 1 & 1 \\
\hline Ireland & 1988 & 0.1 & 1 & 1 & 1 & 1 & 1 \\
\hline Ireland & 1989 & 0.1 & 1 & 1 & 1 & 1 & 1 \\
\hline Ireland & 1990 & 0.1 & 1 & 1 & 1 & 1 & 1 \\
\hline Ireland & 1991 & 0.1 & 1 & 1 & 1 & 1 & 1 \\
\hline Ireland & 1992 & 0.1 & 1 & 1 & 1 & 1 & 1 \\
\hline Ireland & 1993 & 0.1 & 1 & 1 & 1 & 1 & 1 \\
\hline Ireland & 1994 & 0.1 & 1 & 1 & 1 & 1 & 1 \\
\hline Ireland & 1995 & 0.1 & 1 & 1 & 1 & 1 & 1 \\
\hline Ireland & 1996 & 0.1 & 1 & 1 & 1 & 1 & 0.973 \\
\hline Ireland & 1997 & 0.1 & 1 & 1 & 1 & 1 & 0.973 \\
\hline Ireland & 1998 & 0.1 & 1 & 1 & 1 & 1 & 0.973 \\
\hline Ireland & 1999 & 0.1 & 1 & 1 & 1 & 1 & 1 \\
\hline Ireland & 2000 & 0.1 & 1 & 1 & 1 & 1 & 1 \\
\hline Ireland & 2001 & 0.1 & 1 & 1 & 1 & 1 & 1 \\
\hline Ireland & 2002 & 0.1 & 1 & 1 & 1 & 1 & 1 \\
\hline Ireland & 2003 & 0.1 & 1 & 1 & 1 & 1 & 1 \\
\hline Ireland & 2004 & 0.1 & 0.98 & 0.98 & 0.98 & 0.778 & 0.97 \\
\hline Ireland & 2005 & 0.1 & 0.961 & 0.961 & 0.961 & 0.778 & 0.952 \\
\hline Ireland & 2006 & 0.1 & 0.945 & 0.945 & 0.945 & 0.778 & 0.936 \\
\hline Italy & 1980 & 0.36 & 1 & 1 & 1.185 & 1.388 & 1.029 \\
\hline Italy & 1981 & 0.36 & 1 & 1 & 1.185 & 1.388 & 1.029 \\
\hline Italy & 1982 & 0.39 & 1 & 1 & 1.205 & 1.432 & 1.032 \\
\hline Italy & 1983 & 0.41 & 1 & 1 & 1.228 & 1.479 & 1.035 \\
\hline Italy & 1984 & 0.46 & 1 & 1 & 1.281 & 1.59 & 1.044 \\
\hline
\end{tabular}

(To be continued) 
Table A1 - Dataset (continued)

\begin{tabular}{|c|c|c|c|c|c|c|c|}
\hline Country & Year & CIT & Labour & Oth. Curr. & $M \& E$ & B\&S & Foreign \\
\hline Italy & 1985 & 0.46 & 1 & 1 & 1.281 & 1.59 & 1.044 \\
\hline Italy & 1986 & 0.46 & 1 & 1 & 1.281 & 1.59 & 1.044 \\
\hline Italy & 1987 & 0.46 & 1 & 1 & 1.281 & 1.59 & 1.044 \\
\hline Italy & 1988 & 0.46 & 1 & 1 & 1.281 & 1.59 & 1.044 \\
\hline Italy & 1989 & 0.46 & 1 & 1 & 1.281 & 1.59 & 1.044 \\
\hline Italy & 1990 & 0.46 & 1 & 1 & 1.281 & 1.59 & 1.044 \\
\hline Italy & 1991 & 0.48 & 1 & 1 & 1.297 & 1.624 & 1.046 \\
\hline Italy & 1992 & 0.48 & 1 & 1 & 1.297 & 1.624 & 1.046 \\
\hline Italy & 1993 & 0.52 & 1 & 1 & 1.354 & 1.744 & 1.055 \\
\hline Italy & 1994 & 0.52 & 1 & 1 & 1.354 & 1.744 & 1.055 \\
\hline Italy & 1995 & 0.52 & 1 & 1 & 1.354 & 1.744 & 1.055 \\
\hline Italy & 1996 & 0.52 & 1 & 1 & 1.354 & 1.744 & 1.055 \\
\hline Italy & 1997 & 0.52 & 1 & 1 & 1.354 & 1.744 & 1.055 \\
\hline Italy & 1998 & 0.41 & 1 & 1 & 1.228 & 1.478 & 1.035 \\
\hline Italy & 1999 & 0.41 & 1 & 1 & 1.228 & 1.478 & 1.035 \\
\hline Italy & 2000 & 0.41 & 1 & 1 & 1.228 & 1.478 & 1.035 \\
\hline Italy & 2001 & 0.4 & 1 & 1 & 1.218 & 1.459 & 1.034 \\
\hline Italy & 2002 & 0.4 & 1 & 1 & 1.218 & 1.459 & 1.034 \\
\hline Italy & 2003 & 0.38 & 1 & 1 & 1.201 & 1.422 & 1.031 \\
\hline Italy & 2004 & 0.37 & 1 & 1 & 1.192 & 1.404 & 1.03 \\
\hline Italy & 2005 & 0.37 & 1 & 1 & 1.192 & 1.404 & 1.03 \\
\hline Italy & 2006 & 0.37 & 1 & 1 & 1.192 & 1.404 & 1.03 \\
\hline Japan & 1980 & 0.53 & 0.961 & 0.961 & 1.292 & 1.883 & 1.024 \\
\hline Japan & 1981 & 0.55 & 0.959 & 0.959 & 1.32 & 1.962 & 1.028 \\
\hline Japan & 1982 & 0.55 & 0.959 & 0.959 & 1.32 & 1.962 & 1.028 \\
\hline Japan & 1983 & 0.55 & 0.959 & 0.959 & 1.32 & 1.962 & 1.028 \\
\hline Japan & 1984 & 0.57 & 0.958 & 0.958 & 1.339 & 2.018 & 1.03 \\
\hline Japan & 1985 & 0.57 & 0.958 & 0.958 & 1.339 & 2.018 & 1.03 \\
\hline Japan & 1986 & 0.57 & 0.958 & 0.958 & 1.339 & 2.018 & 1.03 \\
\hline Japan & 1987 & 0.55 & 0.959 & 0.959 & 1.32 & 1.962 & 1.028 \\
\hline Japan & 1988 & 0.55 & 0.959 & 0.959 & 1.32 & 1.962 & 1.028 \\
\hline Japan & 1989 & 0.53 & 0.961 & 0.961 & 1.292 & 1.883 & 1.024 \\
\hline Japan & 1990 & 0.5 & 0.963 & 0.963 & 1.261 & 1.794 & 1.02 \\
\hline Japan & 1991 & 0.5 & 0.963 & 0.963 & 1.261 & 1.794 & 1.02 \\
\hline Japan & 1992 & 0.5 & 0.963 & 0.963 & 1.261 & 1.794 & 1.02 \\
\hline Japan & 1993 & 0.5 & 0.963 & 0.963 & 1.261 & 1.794 & 1.02 \\
\hline Japan & 1994 & 0.5 & 0.963 & 0.963 & 1.261 & 1.794 & 1.02 \\
\hline Japan & 1995 & 0.5 & 0.963 & 0.963 & 1.261 & 1.794 & 1.02 \\
\hline Japan & 1996 & 0.5 & 0.963 & 0.963 & 1.261 & 1.794 & 1.02 \\
\hline Japan & 1997 & 0.5 & 0.963 & 0.963 & 1.261 & 1.794 & 1.02 \\
\hline Japan & 1998 & 0.47 & 0.966 & 0.966 & 1.227 & 1.699 & 1.015 \\
\hline Japan & 1999 & 0.42 & 0.955 & 0.955 & 1.171 & 1.576 & 0.997 \\
\hline Japan & 2000 & 0.42 & 0.955 & 0.955 & 1.171 & 1.576 & 0.997 \\
\hline Japan & 2001 & 0.42 & 0.955 & 0.955 & 1.171 & 1.576 & 0.997 \\
\hline Japan & 2002 & 0.42 & 0.955 & 0.955 & 1.171 & 1.576 & 0.997 \\
\hline Japan & 2003 & 0.42 & 0.955 & 0.955 & 1.171 & 1.576 & 0.997 \\
\hline Japan & 2004 & 0.42 & 0.809 & 0.809 & 0.87 & 1.576 & 0.85 \\
\hline Japan & 2005 & 0.42 & 0.809 & 0.809 & 0.87 & 1.576 & 0.85 \\
\hline
\end{tabular}

(To be continued) 
Table A1 - Dataset (continued)

\begin{tabular}{|c|c|c|c|c|c|c|c|}
\hline Country & Year & CIT & Labour & Oth. Curr. & M\&E & B\&S & Foreign \\
\hline Japan & 2006 & 0.42 & 0.809 & 0.809 & 0.87 & 1.576 & 0.85 \\
\hline Korea & 1980 & 0.3 & 1 & 1 & 1.102 & 1.259 & 1.018 \\
\hline Korea & 1981 & 0.3 & 1 & 1 & 1.102 & 1.259 & 1.018 \\
\hline Korea & 1982 & 0.3 & 1 & 1 & 1.102 & 1.259 & 1.018 \\
\hline Korea & 1983 & 0.3 & 1 & 1 & 1.102 & 1.259 & 1.018 \\
\hline Korea & 1984 & 0.3 & 1 & 1 & 1.102 & 1.259 & 1.018 \\
\hline Korea & 1985 & 0.3 & 1 & 1 & 1.102 & 1.259 & 1.018 \\
\hline Korea & 1986 & 0.3 & 1 & 1 & 1.102 & 1.259 & 1.018 \\
\hline Korea & 1987 & 0.3 & 1 & 1 & 1.102 & 1.259 & 1.018 \\
\hline Korea & 1988 & 0.3 & 0.891 & 0.891 & 0.993 & 1.188 & 0.911 \\
\hline Korea & 1989 & 0.3 & 0.891 & 0.891 & 0.993 & 1.188 & 0.911 \\
\hline Korea & 1990 & 0.3 & 0.891 & 0.891 & 0.993 & 1.188 & 0.911 \\
\hline Korea & 1991 & 0.34 & 0.884 & 0.884 & 1.006 & 1.236 & 0.908 \\
\hline Korea & 1992 & 0.34 & 0.884 & 0.884 & 1.006 & 1.236 & 0.908 \\
\hline Korea & 1993 & 0.34 & 0.884 & 0.884 & 1.006 & 1.236 & 0.908 \\
\hline Korea & 1994 & 0.32 & 0.888 & 0.888 & 0.999 & 1.211 & 0.909 \\
\hline Korea & 1995 & 0.3 & 0.891 & 0.891 & 0.993 & 1.188 & 0.911 \\
\hline Korea & 1996 & 0.28 & 0.894 & 0.894 & 0.986 & 1.166 & 0.912 \\
\hline Korea & 1997 & 0.28 & 0.856 & 0.856 & 0.995 & 0.995 & 0.87 \\
\hline Korea & 1998 & 0.28 & 0.856 & 0.856 & 0.995 & 0.995 & 0.87 \\
\hline Korea & 1999 & 0.28 & 0.856 & 0.856 & 0.995 & 0.995 & 0.87 \\
\hline Korea & 2000 & 0.28 & 0.856 & 0.856 & 0.995 & 0.995 & 0.87 \\
\hline Korea & 2001 & 0.28 & 0.856 & 0.856 & 0.995 & 0.995 & 0.87 \\
\hline Korea & 2002 & 0.27 & 0.858 & 0.858 & 0.993 & 0.993 & 0.871 \\
\hline Korea & 2003 & 0.27 & 0.858 & 0.858 & 0.993 & 0.993 & 0.897 \\
\hline Korea & 2004 & 0.27 & 0.858 & 0.858 & 0.993 & 0.993 & 0.897 \\
\hline Korea & 2005 & 0.25 & 0.862 & 0.862 & 0.989 & 0.989 & 0.899 \\
\hline Korea & 2006 & 0.25 & 0.862 & 0.862 & 0.989 & 0.989 & 0.899 \\
\hline Mexico & 1980 & 0.42 & 1 & 1 & 1.064 & 1.385 & 1.022 \\
\hline Mexico & 1981 & 0.42 & 0.986 & 0.986 & 0.719 & 1.04 & 0.974 \\
\hline Mexico & 1982 & 0.42 & 0.986 & 0.986 & 0.719 & 1.04 & 0.974 \\
\hline Mexico & 1983 & 0.42 & 1 & 1 & 1.064 & 1.385 & 1.022 \\
\hline Mexico & 1984 & 0.42 & 1 & 1 & 1.064 & 1.385 & 1.022 \\
\hline Mexico & 1985 & 0.42 & 1 & 1 & 1.064 & 1.385 & 1.022 \\
\hline Mexico & 1986 & 0.42 & 1 & 1 & 1.064 & 1.385 & 1.022 \\
\hline Mexico & 1987 & 0.35 & 1 & 1 & 1.047 & 1.286 & 1.017 \\
\hline Mexico & 1988 & 0.35 & 1 & 1 & 1.047 & 1.286 & 1.017 \\
\hline Mexico & 1989 & 0.37 & 1 & 1 & 1.052 & 1.312 & 1.018 \\
\hline Mexico & 1990 & 0.36 & 1 & 1 & 1.05 & 1.299 & 1.017 \\
\hline Mexico & 1991 & 0.35 & 1 & 1 & 1.047 & 1.286 & 1.017 \\
\hline Mexico & 1992 & 0.35 & 1 & 1 & 1.047 & 1.286 & 1.017 \\
\hline Mexico & 1993 & 0.35 & 1 & 1 & 1.047 & 1.286 & 1.017 \\
\hline Mexico & 1994 & 0.34 & 1 & 1 & 1.045 & 1.274 & 1.016 \\
\hline Mexico & 1995 & 0.34 & 1 & 1 & 1.045 & 1.274 & 1.016 \\
\hline Mexico & 1996 & 0.34 & 1 & 1 & 1.045 & 1.274 & 1.016 \\
\hline Mexico & 1997 & 0.34 & 0.948 & 0.948 & 1.045 & 1.274 & 0.969 \\
\hline Mexico & 1998 & 0.34 & 0.948 & 0.948 & 1.045 & 1.274 & 0.969 \\
\hline Mexico & 1999 & 0.35 & 0.947 & 0.947 & 1.047 & 1.286 & 0.969 \\
\hline
\end{tabular}

(To be continued) 
Table A1 - Dataset (continued)

\begin{tabular}{|c|c|c|c|c|c|c|c|}
\hline Country & Year & CIT & Labour & Oth. Curr. & M\&E & B\&S & Foreign \\
\hline Mexico & 2000 & 0.35 & 0.947 & 0.947 & 1.047 & 1.286 & 0.969 \\
\hline Mexico & 2001 & 0.35 & 0.947 & 0.947 & 1.047 & 1.286 & 0.969 \\
\hline Mexico & 2002 & 0.35 & 0.947 & 0.947 & 1.047 & 1.286 & 0.969 \\
\hline Mexico & 2003 & 0.34 & 0.545 & 0.545 & 1.045 & 1.274 & 0.607 \\
\hline Mexico & 2004 & 0.33 & 0.552 & 0.552 & 1.043 & 1.262 & 0.612 \\
\hline Mexico & 2005 & 0.3 & 0.571 & 0.571 & 1.038 & 1.228 & 0.628 \\
\hline Mexico & 2006 & 0.29 & 0.577 & 0.577 & 1.036 & 1.217 & 0.632 \\
\hline Netherlands & 1980 & 0.48 & 1 & 1 & 1.153 & 1.554 & 1.035 \\
\hline Netherlands & 1981 & 0.48 & 1 & 1 & 1.153 & 1.554 & 1.035 \\
\hline Netherlands & 1982 & 0.48 & 1 & 1 & 1.153 & 1.554 & 1.035 \\
\hline Netherlands & 1983 & 0.48 & 1 & 1 & 1.153 & 1.554 & 1.035 \\
\hline Netherlands & 1984 & 0.43 & 1 & 1 & 1.125 & 1.453 & 1.029 \\
\hline Netherlands & 1985 & 0.43 & 1 & 1 & 1.125 & 1.453 & 1.029 \\
\hline Netherlands & 1986 & 0.42 & 1 & 1 & 1.12 & 1.435 & 1.028 \\
\hline Netherlands & 1987 & 0.42 & 1 & 1 & 1.12 & 1.435 & 1.028 \\
\hline Netherlands & 1988 & 0.42 & 1 & 1 & 1.12 & 1.435 & 1.028 \\
\hline Netherlands & 1989 & 0.35 & 1 & 1 & 1.089 & 1.323 & 1.021 \\
\hline Netherlands & 1990 & 0.35 & 1 & 1 & 1.089 & 1.323 & 1.021 \\
\hline Netherlands & 1991 & 0.35 & 1 & 1 & 1.089 & 1.323 & 1.021 \\
\hline Netherlands & 1992 & 0.35 & 1 & 1 & 1.089 & 1.323 & 1.021 \\
\hline Netherlands & 1993 & 0.35 & 1 & 1 & 1.089 & 1.323 & 1.021 \\
\hline Netherlands & 1994 & 0.35 & 0.808 & 1 & 1.089 & 1.323 & 0.905 \\
\hline Netherlands & 1995 & 0.35 & 0.808 & 1 & 1.089 & 1.323 & 0.905 \\
\hline Netherlands & 1996 & 0.37 & 0.802 & 1 & 1.098 & 1.353 & 0.903 \\
\hline Netherlands & 1997 & 0.36 & 0.805 & 1 & 1.093 & 1.338 & 0.904 \\
\hline Netherlands & 1998 & 0.35 & 0.808 & 1 & 1.089 & 1.323 & 0.905 \\
\hline Netherlands & 1999 & 0.35 & 0.808 & 1 & 1.089 & 1.323 & 0.905 \\
\hline Netherlands & 2000 & 0.35 & 0.808 & 1 & 1.089 & 1.323 & 0.905 \\
\hline Netherlands & 2001 & 0.35 & 0.808 & 1 & 1.089 & 1.323 & 0.905 \\
\hline Netherlands & 2002 & 0.35 & 0.802 & 1 & 1.087 & 1.316 & 0.901 \\
\hline Netherlands & 2003 & 0.35 & 0.802 & 1 & 1.087 & 1.316 & 0.901 \\
\hline Netherlands & 2004 & 0.35 & 0.786 & 1 & 1.087 & 1.316 & 0.892 \\
\hline Netherlands & 2005 & 0.32 & 0.796 & 1 & 1.076 & 1.276 & 0.895 \\
\hline Netherlands & 2006 & 0.3 & 0.801 & 1 & 1.07 & 1.253 & 0.897 \\
\hline New Zealand & 1980 & 0.45 & 1 & 1 & 1.199 & 1.561 & 1.038 \\
\hline New Zealand & 1981 & 0.45 & 1 & 1 & 1.199 & 1.561 & 1.038 \\
\hline New Zealand & 1982 & 0.45 & 1 & 1 & 1.199 & 1.561 & 1.038 \\
\hline New Zealand & 1983 & 0.45 & 1 & 1 & 1.199 & 1.561 & 1.038 \\
\hline New Zealand & 1984 & 0.45 & 1 & 1 & 1.199 & 1.561 & 1.038 \\
\hline
\end{tabular}

(To be continued) 
Table A1 - Dataset (continued)

\begin{tabular}{|c|c|c|c|c|c|c|c|}
\hline Country & Year & CIT & Labour & Oth. Curr. & M\&E & B\&S & Foreign \\
\hline New Zealand & 1985 & 0.45 & 1 & 1 & 1.199 & 1.561 & 1.038 \\
\hline New Zealand & 1986 & 0.45 & 1 & 1 & 1.199 & 1.561 & 1.038 \\
\hline New Zealand & 1987 & 0.48 & 1 & 1 & 1.225 & 1.633 & 1.043 \\
\hline New Zealand & 1988 & 0.48 & 1 & 1 & 1.225 & 1.633 & 1.043 \\
\hline New Zealand & 1989 & 0.28 & 1 & 1 & 1.095 & 1.267 & 1.018 \\
\hline New Zealand & 1990 & 0.33 & 1 & 1 & 1.12 & 1.338 & 1.023 \\
\hline New Zealand & 1991 & 0.33 & 1 & 1 & 1.12 & 1.338 & 1.023 \\
\hline New Zealand & 1992 & 0.33 & 1 & 1 & 1.12 & 1.338 & 1.023 \\
\hline New Zealand & 1993 & 0.33 & 1 & 1 & 1.12 & 1.338 & 1.023 \\
\hline New Zealand & 1994 & 0.33 & 1 & 1 & 1.12 & 1.338 & 1.023 \\
\hline New Zealand & 1995 & 0.33 & 1 & 1 & 1.12 & 1.338 & 1.023 \\
\hline New Zealand & 1996 & 0.33 & 1 & 1 & 1.12 & 1.338 & 1.023 \\
\hline New Zealand & 1997 & 0.33 & 1 & 1 & 1.12 & 1.338 & 1.023 \\
\hline New Zealand & 1998 & 0.33 & 1 & 1 & 1.12 & 1.338 & 1.023 \\
\hline New Zealand & 1999 & 0.33 & 1 & 1 & 1.12 & 1.338 & 1.023 \\
\hline New Zealand & 2000 & 0.33 & 1 & 1 & 1.12 & 1.338 & 1.023 \\
\hline New Zealand & 2001 & 0.33 & 1 & 1 & 1.12 & 1.338 & 1.023 \\
\hline New Zealand & 2002 & 0.33 & 1 & 1 & 1.12 & 1.338 & 1.023 \\
\hline New Zealand & 2003 & 0.33 & 1 & 1 & 1.12 & 1.338 & 1.023 \\
\hline New Zealand & 2004 & 0.33 & 1 & 1 & 1.12 & 1.338 & 1.023 \\
\hline New Zealand & 2005 & 0.33 & 1 & 1 & 1.12 & 1.338 & 1.023 \\
\hline New Zealand & 2006 & 0.33 & 1 & 1 & 1.12 & 1.338 & 1.023 \\
\hline Norway & 1980 & 0.51 & 1 & 1 & 1.275 & 1.654 & 1.046 \\
\hline Norway & 1981 & 0.51 & 1 & 1 & 1.275 & 1.654 & 1.046 \\
\hline Norway & 1982 & 0.51 & 1 & 1 & 1.275 & 1.654 & 1.046 \\
\hline Norway & 1983 & 0.51 & 1 & 1 & 1.275 & 1.654 & 1.046 \\
\hline Norway & 1984 & 0.51 & 1 & 1 & 1.275 & 1.654 & 1.046 \\
\hline Norway & 1985 & 0.51 & 1 & 1 & 1.275 & 1.654 & 1.046 \\
\hline Norway & 1986 & 0.51 & 1 & 1 & 1.275 & 1.654 & 1.046 \\
\hline Norway & 1987 & 0.51 & 1 & 1 & 1.275 & 1.654 & 1.046 \\
\hline Norway & 1988 & 0.51 & 1 & 1 & 1.275 & 1.654 & 1.046 \\
\hline Norway & 1989 & 0.51 & 1 & 1 & 1.275 & 1.654 & 1.046 \\
\hline Norway & 1990 & 0.51 & 1 & 1 & 1.275 & 1.654 & 1.046 \\
\hline Norway & 1991 & 0.51 & 1 & 1 & 1.275 & 1.654 & 1.046 \\
\hline Norway & 1992 & 0.28 & 1 & 1 & 1.104 & 1.246 & 1.018 \\
\hline Norway & 1993 & 0.28 & 1 & 1 & 1.104 & 1.246 & 1.018 \\
\hline Norway & 1994 & 0.28 & 1 & 1 & 1.104 & 1.246 & 1.018 \\
\hline Norway & 1995 & 0.28 & 1 & 1 & 1.104 & 1.246 & 1.018 \\
\hline Norway & 1996 & 0.28 & 1 & 1 & 1.104 & 1.246 & 1.018 \\
\hline Norway & 1997 & 0.28 & 1 & 1 & 1.104 & 1.246 & 1.018 \\
\hline Norway & 1998 & 0.28 & 1 & 1 & 1.104 & 1.246 & 1.018 \\
\hline Norway & 1999 & 0.28 & 1 & 1 & 1.104 & 1.246 & 1.018 \\
\hline
\end{tabular}

(To be continued) 
Table A1 - Dataset (continued)

\begin{tabular}{|c|c|c|c|c|c|c|c|}
\hline Country & Year & CIT & Labour & Oth. Curr. & M\&E & B\&S & Foreign \\
\hline Norway & 2000 & 0.28 & 1 & 1 & 1.104 & 1.246 & 1.018 \\
\hline Norway & 2001 & 0.28 & 1 & 1 & 1.104 & 1.246 & 1.018 \\
\hline Norway & 2002 & 0.28 & 0.75 & 0.75 & 1.104 & 1.246 & 0.793 \\
\hline Norway & 2003 & 0.28 & 0.75 & 0.75 & 1.104 & 1.246 & 0.793 \\
\hline Norway & 2004 & 0.28 & 0.75 & 0.75 & 1.104 & 1.246 & 0.793 \\
\hline Norway & 2005 & 0.28 & 0.75 & 0.75 & 1.104 & 1.246 & 0.793 \\
\hline Norway & 2006 & 0.28 & 0.75 & 0.75 & 1.104 & 1.246 & 0.793 \\
\hline Poland & 1980 & - & - & - & - & - & - \\
\hline Poland & 1981 & - & - & - & - & - & - \\
\hline Poland & 1982 & - & - & - & - & - & - \\
\hline Poland & 1983 & - & - & - & - & - & - \\
\hline Poland & 1984 & - & - & - & - & - & - \\
\hline Poland & 1985 & - & - & - & - & - & - \\
\hline Poland & 1986 & - & - & - & - & - & - \\
\hline Poland & 1987 & - & - & - & - & - & - \\
\hline Poland & 1988 & - & - & - & - & - & - \\
\hline Poland & 1989 & - & - & - & - & - & - \\
\hline Poland & 1990 & - & - & - & - & - & - \\
\hline Poland & 1991 & 0.4 & 1 & 1 & 1.086 & 1.487 & 1.081 \\
\hline Poland & 1992 & 0.4 & 1 & 1 & 1.086 & 1.487 & 1.081 \\
\hline Poland & 1993 & 0.4 & 1 & 1 & 1.086 & 1.487 & 1.081 \\
\hline Poland & 1994 & 0.4 & 1 & 1 & 1.086 & 1.487 & 1.081 \\
\hline Poland & 1995 & 0.4 & 1 & 1 & 1.086 & 1.487 & 1.081 \\
\hline Poland & 1996 & 0.4 & 1 & 1 & 1.086 & 1.487 & 1.081 \\
\hline Poland & 1997 & 0.4 & 1 & 1 & 1.086 & 1.487 & 1.081 \\
\hline Poland & 1998 & 0.36 & 1 & 1 & 1.072 & 1.411 & 1.069 \\
\hline Poland & 1999 & 0.34 & 1 & 1 & 1.066 & 1.377 & 1.063 \\
\hline Poland & 2000 & 0.28 & 1 & 1 & 1.05 & 1.284 & 1.048 \\
\hline Poland & 2001 & 0.28 & 1 & 1 & 1.05 & 1.284 & 1.048 \\
\hline Poland & 2002 & 0.28 & 1 & 1 & 1.05 & 1.284 & 1.048 \\
\hline Poland & 2003 & 0.27 & 1 & 1 & 1.047 & 1.27 & 1.045 \\
\hline Poland & 2004 & 0.19 & 1 & 1 & 1.03 & 1.171 & 1.029 \\
\hline Poland & 2005 & 0.19 & 1 & 0.904 & 1.03 & 1.171 & 0.983 \\
\hline Poland & 2006 & 0.19 & 1 & 0.904 & 1.03 & 1.171 & 0.983 \\
\hline Portugal & 1980 & 0.23 & 1 & 1 & 1.038 & 1.159 & 1.01 \\
\hline Portugal & 1981 & 0.23 & 1 & 1 & 1.038 & 1.159 & 1.01 \\
\hline Portugal & 1982 & 0.4 & 1 & 1 & 1.086 & 1.355 & 1.022 \\
\hline Portugal & 1983 & 0.4 & 1 & 1 & 1.086 & 1.355 & 1.022 \\
\hline Portugal & 1984 & 0.4 & 1 & 1 & 1.086 & 1.355 & 1.022 \\
\hline Portugal & 1985 & 0.4 & 1 & 1 & 1.086 & 1.355 & 1.022 \\
\hline Portugal & 1986 & 0.4 & 1 & 1 & 1.086 & 1.355 & 1.022 \\
\hline Portugal & 1987 & 0.35 & 1 & 1 & 1.069 & 1.286 & 1.018 \\
\hline Portugal & 1988 & 0.35 & 1 & 1 & 1.069 & 1.286 & 1.018 \\
\hline Portugal & 1989 & 0.37 & 1 & 1 & 1.074 & 1.306 & 1.019 \\
\hline Portugal & 1990 & 0.37 & 1 & 1 & 1.074 & 1.306 & 1.019 \\
\hline Portugal & 1991 & 0.36 & 1 & 1 & 1.072 & 1.299 & 1.019 \\
\hline Portugal & 1992 & 0.36 & 1 & 1 & 1.072 & 1.299 & 1.019 \\
\hline Portugal & 1993 & 0.36 & 1 & 1 & 1.072 & 1.299 & 1.019 \\
\hline
\end{tabular}

(To be continued) 
Table A1 - Dataset (continued)

\begin{tabular}{|c|c|c|c|c|c|c|c|}
\hline Country & Year & CIT & Labour & Oth. Curr. & M\&E & B\&S & Foreign \\
\hline Portugal & 1994 & 0.36 & 1 & 1 & 1.072 & 1.299 & 1.019 \\
\hline Portugal & 1995 & 0.36 & 1 & 1 & 1.072 & 1.299 & 1.019 \\
\hline Portugal & 1996 & 0.36 & 1 & 1 & 1.072 & 1.299 & 1.019 \\
\hline Portugal & 1997 & 0.36 & 0.816 & 0.816 & 1.072 & 1.299 & 1.019 \\
\hline Portugal & 1998 & 0.37 & 0.813 & 0.813 & 1.075 & 1.312 & 1.019 \\
\hline Portugal & 1999 & 0.34 & 0.822 & 0.822 & 1.066 & 1.274 & 1.017 \\
\hline Portugal & 2000 & 0.32 & 0.827 & 0.827 & 1.06 & 1.25 & 1.016 \\
\hline Portugal & 2001 & 0.32 & 0.648 & 0.648 & 1.06 & 1.25 & 1.016 \\
\hline Portugal & 2002 & 0.3 & 0.658 & 0.658 & 1.055 & 1.228 & 1.014 \\
\hline Portugal & 2003 & 0.3 & 0.658 & 0.658 & 1.055 & 1.228 & 1.014 \\
\hline Portugal & 2004 & 0.25 & 1 & 1 & 1.043 & 1.177 & 1.011 \\
\hline Portugal & 2005 & 0.25 & 0.68 & 0.68 & 1.043 & 1.177 & 1.011 \\
\hline Portugal & 2006 & 0.25 & 0.68 & 0.68 & 1.043 & 1.177 & 1.011 \\
\hline Spain & 1980 & 0.33 & 0.851 & 0.851 & 0.851 & 0.966 & 0.857 \\
\hline Spain & 1981 & 0.33 & 0.851 & 0.851 & 0.851 & 0.966 & 0.857 \\
\hline Spain & 1982 & 0.33 & 0.851 & 0.851 & 0.851 & 0.966 & 0.857 \\
\hline Spain & 1983 & 0.33 & 0.851 & 0.851 & 0.851 & 0.966 & 0.857 \\
\hline Spain & 1984 & 0.35 & 0.769 & 0.769 & 0.538 & 0.665 & 0.752 \\
\hline Spain & 1985 & 0.35 & 0.769 & 0.769 & 0.538 & 0.665 & 0.752 \\
\hline Spain & 1986 & 0.35 & 0.769 & 0.769 & 0.538 & 0.665 & 0.752 \\
\hline Spain & 1987 & 0.35 & 0.769 & 0.769 & 0.538 & 0.665 & 0.752 \\
\hline Spain & 1988 & 0.35 & 0.769 & 0.769 & 0.538 & 0.665 & 0.752 \\
\hline Spain & 1989 & 0.35 & 0.769 & 0.769 & 0.538 & 0.665 & 0.752 \\
\hline Spain & 1990 & 0.35 & 0.769 & 0.769 & 0.538 & 0.665 & 0.752 \\
\hline Spain & 1991 & 0.35 & 0.769 & 0.769 & 0.538 & 0.665 & 0.752 \\
\hline Spain & 1992 & 0.35 & 0.739 & 0.739 & 0.508 & 0.634 & 0.722 \\
\hline Spain & 1993 & 0.35 & 0.739 & 0.739 & 0.508 & 0.634 & 0.722 \\
\hline Spain & 1994 & 0.35 & 0.739 & 0.739 & 0.508 & 0.634 & 0.722 \\
\hline Spain & 1995 & 0.35 & 0.739 & 0.739 & 0.508 & 0.634 & 0.722 \\
\hline Spain & 1996 & 0.35 & 0.652 & 0.652 & 0.652 & 1.175 & 0.678 \\
\hline Spain & 1997 & 0.35 & 0.652 & 0.652 & 0.652 & 1.367 & 0.687 \\
\hline Spain & 1998 & 0.35 & 0.652 & 0.652 & 0.652 & 1.367 & 0.687 \\
\hline Spain & 1999 & 0.35 & 0.652 & 0.652 & 0.652 & 1.367 & 0.687 \\
\hline Spain & 2000 & 0.35 & 0.652 & 0.652 & 0.652 & 1.367 & 0.687 \\
\hline Spain & 2001 & 0.35 & 0.498 & 0.498 & 1 & 1.367 & 0.566 \\
\hline Spain & 2002 & 0.35 & 0.498 & 0.498 & 1 & 1.367 & 0.566 \\
\hline Spain & 2003 & 0.35 & 0.498 & 0.498 & 1 & 1.367 & 0.566 \\
\hline Spain & 2004 & 0.35 & 0.498 & 0.498 & 1 & 1.367 & 0.566 \\
\hline Spain & 2005 & 0.35 & 0.498 & 0.498 & 1 & 1.367 & 0.566 \\
\hline Spain & 2006 & 0.35 & 0.498 & 0.498 & 1 & 1.367 & 0.566 \\
\hline Sweden & 1980 & 0.4 & 0.877 & 1 & 1.117 & 1.4 & 0.952 \\
\hline Sweden & 1981 & 0.4 & 0.877 & 1 & 1.117 & 1.4 & 0.952 \\
\hline Sweden & 1982 & 0.4 & 0.898 & 1 & 1.117 & 1.4 & 0.965 \\
\hline Sweden & 1983 & 0.4 & 0.898 & 1 & 1.117 & 1.4 & 0.965 \\
\hline Sweden & 1984 & 0.32 & 1 & 1 & 1.082 & 1.283 & 1.018 \\
\hline Sweden & 1985 & 0.52 & 1 & 1 & 1.19 & 1.651 & 1.042 \\
\hline Sweden & 1986 & 0.52 & 1 & 1 & 1.19 & 1.651 & 1.042 \\
\hline Sweden & 1987 & 0.52 & 1 & 1 & 1.19 & 1.651 & 1.042 \\
\hline
\end{tabular}

(To be continued) 
Table A1 - Dataset (continued)

\begin{tabular}{|c|c|c|c|c|c|c|c|}
\hline Country & Year & CIT & Labour & Oth. Curr. & M\&E & B\&S & Foreign \\
\hline Sweden & 1988 & 0.52 & 1 & 1 & 1.19 & 1.651 & 1.042 \\
\hline Sweden & 1989 & 0.52 & 1 & 1 & 1.19 & 1.651 & 1.042 \\
\hline Sweden & 1990 & 0.4 & 1 & 1 & 1.117 & 1.4 & 1.026 \\
\hline Sweden & 1991 & 0.3 & 1 & 1 & 1.075 & 1.257 & 1.017 \\
\hline Sweden & 1992 & 0.3 & 1 & 1 & 1.075 & 1.257 & 1.017 \\
\hline Sweden & 1993 & 0.3 & 1 & 1 & 1.075 & 1.257 & 1.017 \\
\hline Sweden & 1994 & 0.28 & 1 & 1 & 1.068 & 1.234 & 1.015 \\
\hline Sweden & 1995 & 0.28 & 1 & 1 & 1.068 & 1.234 & 1.015 \\
\hline Sweden & 1996 & 0.28 & 1 & 1 & 1.068 & 1.234 & 1.015 \\
\hline Sweden & 1997 & 0.28 & 1 & 1 & 1.068 & 1.234 & 1.015 \\
\hline Sweden & 1998 & 0.28 & 1 & 1 & 1.068 & 1.234 & 1.015 \\
\hline Sweden & 1999 & 0.28 & 1 & 1 & 1.068 & 1.234 & 1.015 \\
\hline Sweden & 2000 & 0.28 & 1 & 1 & 1.068 & 1.234 & 1.015 \\
\hline Sweden & 2001 & 0.28 & 1 & 1 & 1.068 & 1.234 & 1.015 \\
\hline Sweden & 2002 & 0.28 & 1 & 1 & 1.068 & 1.234 & 1.015 \\
\hline Sweden & 2003 & 0.28 & 1 & 1 & 1.068 & 1.234 & 1.015 \\
\hline Sweden & 2004 & 0.28 & 1 & 1 & 1.068 & 1.234 & 1.015 \\
\hline Sweden & 2005 & 0.28 & 1 & 1 & 1.068 & 1.234 & 1.015 \\
\hline Sweden & 2006 & 0.28 & 1 & 1 & 1.068 & 1.234 & 1.015 \\
\hline Switzerland & 1980 & 0.3 & 1 & 1 & 1.052 & 1.221 & 1.014 \\
\hline Switzerland & 1981 & 0.3 & 1 & 1 & 1.052 & 1.221 & 1.014 \\
\hline Switzerland & 1982 & 0.3 & 1 & 1 & 1.052 & 1.221 & 1.014 \\
\hline Switzerland & 1983 & 0.3 & 1 & 1 & 1.052 & 1.221 & 1.014 \\
\hline Switzerland & 1984 & 0.3 & 1 & 1 & 1.052 & 1.221 & 1.014 \\
\hline Switzerland & 1985 & 0.3 & 1 & 1 & 1.052 & 1.221 & 1.014 \\
\hline Switzerland & 1986 & 0.3 & 1 & 1 & 1.052 & 1.221 & 1.014 \\
\hline Switzerland & 1987 & 0.3 & 1 & 1 & 1.052 & 1.221 & 1.014 \\
\hline Switzerland & 1988 & 0.3 & 1 & 1 & 1.052 & 1.221 & 1.014 \\
\hline Switzerland & 1989 & 0.3 & 1 & 1 & 1.052 & 1.221 & 1.014 \\
\hline Switzerland & 1990 & 0.29 & 1 & 1 & 1.048 & 1.204 & 1.013 \\
\hline Switzerland & 1991 & 0.29 & 1 & 1 & 1.048 & 1.204 & 1.013 \\
\hline Switzerland & 1992 & 0.29 & 1 & 1 & 1.048 & 1.204 & 1.013 \\
\hline Switzerland & 1993 & 0.29 & 1 & 1 & 1.048 & 1.204 & 1.013 \\
\hline Switzerland & 1994 & 0.29 & 1 & 1 & 1.048 & 1.204 & 1.013 \\
\hline Switzerland & 1995 & 0.29 & 1 & 1 & 1.048 & 1.204 & 1.013 \\
\hline Switzerland & 1996 & 0.29 & 1 & 1 & 1.048 & 1.204 & 1.013 \\
\hline Switzerland & 1997 & 0.29 & 1 & 1 & 1.048 & 1.204 & 1.013 \\
\hline Switzerland & 1998 & 0.28 & 1 & 1 & 1.046 & 1.194 & 1.012 \\
\hline Switzerland & 1999 & 0.25 & 1 & 1 & 1.04 & 1.171 & 1.011 \\
\hline Switzerland & 2000 & 0.25 & 1 & 1 & 1.04 & 1.171 & 1.011 \\
\hline Switzerland & 2001 & 0.25 & 1 & 1 & 1.039 & 1.168 & 1.01 \\
\hline Switzerland & 2002 & 0.25 & 1 & 1 & 1.039 & 1.166 & 1.01 \\
\hline Switzerland & 2003 & 0.24 & 1 & 1 & 1.038 & 1.162 & 1.01 \\
\hline Switzerland & 2004 & 0.24 & 1 & 1 & 1.038 & 1.162 & 1.01 \\
\hline Switzerland & 2005 & 0.21 & 1 & 1 & 1.032 & 1.138 & 1.009 \\
\hline Switzerland & 2006 & 0.21 & 1 & 1 & 1.032 & 1.138 & 1.009 \\
\hline United Kingdom & 1980 & 0.52 & 1 & 1 & 1 & 1 & 1 \\
\hline United Kingdom & 1981 & 0.52 & 1 & 1 & 1 & 1 & 1 \\
\hline
\end{tabular}

(To be continued) 
Table A1 - Dataset (continued)

\begin{tabular}{|c|c|c|c|c|c|c|c|}
\hline Country & Year & CIT & Labour & Oth. Curr. & M\&E & B\&S & Foreign \\
\hline United Kingdom & 1982 & 0.52 & 1 & 1 & 1 & 1 & 1 \\
\hline United Kingdom & 1983 & 0.52 & 1 & 1 & 1 & 1 & 1 \\
\hline United Kingdom & 1984 & 0.5 & 1 & 1 & 1 & 1 & 1 \\
\hline United Kingdom & 1985 & 0.45 & 1 & 1 & 1 & 1 & 1 \\
\hline United Kingdom & 1986 & 0.4 & 1 & 1 & 1 & 1 & 1 \\
\hline United Kingdom & 1987 & 0.35 & 1 & 1 & 1 & 1 & 1 \\
\hline United Kingdom & 1988 & 0.35 & 1 & 1 & 1 & 1 & 1 \\
\hline United Kingdom & 1989 & 0.35 & 1 & 1 & 1 & 1 & 1 \\
\hline United Kingdom & 1990 & 0.35 & 1 & 1 & 1 & 1 & 1 \\
\hline United Kingdom & 1991 & 0.35 & 1 & 1 & 1 & 1 & 1 \\
\hline United Kingdom & 1992 & 0.33 & 1 & 1 & 1 & 1 & 1 \\
\hline United Kingdom & 1993 & 0.33 & 1 & 1 & 1 & 1 & 1 \\
\hline United Kingdom & 1994 & 0.33 & 1 & 1 & 1 & 1 & 1 \\
\hline United Kingdom & 1995 & 0.33 & 1 & 1 & 1 & 1 & 1 \\
\hline United Kingdom & 1996 & 0.33 & 1 & 1 & 1 & 1 & 1 \\
\hline United Kingdom & 1997 & 0.33 & 1 & 1 & 1 & 1 & 1 \\
\hline United Kingdom & 1998 & 0.31 & 1 & 1 & 1 & 1 & 1 \\
\hline United Kingdom & 1999 & 0.31 & 1 & 1 & 1 & 1 & 1 \\
\hline United Kingdom & 2000 & 0.3 & 1 & 1 & 1 & 1 & 1 \\
\hline United Kingdom & 2001 & 0.3 & 0.893 & 0.893 & 1 & 1 & 0.904 \\
\hline United Kingdom & 2002 & 0.3 & 0.893 & 0.893 & 1 & 1 & 0.904 \\
\hline United Kingdom & 2003 & 0.3 & 0.893 & 0.893 & 1 & 1 & 0.904 \\
\hline United Kingdom & 2004 & 0.3 & 0.893 & 0.893 & 1 & 1 & 0.904 \\
\hline United Kingdom & 2005 & 0.3 & 0.893 & 0.893 & 1 & 1 & 0.904 \\
\hline United Kingdom & 2006 & 0.3 & 0.893 & 0.893 & 1 & 1 & 0.904 \\
\hline United States & 1980 & 0.46 & 1 & 1 & 1.141 & 1.377 & 1.026 \\
\hline United States & 1981 & 0.46 & 0.921 & 0.921 & 1.141 & 1.377 & 0.955 \\
\hline United States & 1982 & 0.46 & 0.921 & 0.921 & 1.141 & 1.377 & 0.955 \\
\hline United States & 1983 & 0.46 & 0.921 & 0.921 & 1.141 & 1.377 & 0.955 \\
\hline United States & 1984 & 0.46 & 0.921 & 0.921 & 1.141 & 1.377 & 0.955 \\
\hline United States & 1985 & 0.46 & 0.921 & 0.921 & 1.141 & 1.425 & 0.957 \\
\hline United States & 1986 & 0.46 & 0.937 & 0.937 & 1.141 & 1.439 & 0.972 \\
\hline United States & 1987 & 0.4 & 0.943 & 0.943 & 1.111 & 1.483 & 0.979 \\
\hline United States & 1988 & 0.34 & 0.948 & 0.948 & 1.086 & 1.373 & 0.977 \\
\hline United States & 1989 & 0.34 & 0.957 & 0.957 & 1.086 & 1.373 & 0.985 \\
\hline United States & 1990 & 0.34 & 0.958 & 0.958 & 1.086 & 1.373 & 0.986 \\
\hline United States & 1991 & 0.34 & 0.958 & 0.958 & 1.086 & 1.373 & 0.986 \\
\hline United States & 1992 & 0.34 & 0.958 & 0.958 & 1.086 & 1.373 & 0.986 \\
\hline
\end{tabular}

(To be continued) 
Table A1 - Dataset (continued)

\begin{tabular}{lccccccc}
\hline Country & Year & CIT & Labour & Oth. Curr. & M\&E & B\&S & Foreign \\
\hline United States & 1993 & 0.35 & 0.958 & 0.958 & 1.089 & 1.39 & 0.987 \\
United States & 1994 & 0.35 & 0.958 & 0.958 & 1.089 & 1.39 & 0.987 \\
United States & 1995 & 0.35 & 1 & 1 & 1.089 & 1.39 & 1.024 \\
United States & 1996 & 0.35 & 0.958 & 0.958 & 1.089 & 1.39 & 0.987 \\
United States & 1997 & 0.35 & 0.958 & 0.958 & 1.089 & 1.39 & 0.987 \\
United States & 1998 & 0.35 & 0.958 & 0.958 & 1.089 & 1.39 & 0.987 \\
United States & 1999 & 0.35 & 0.958 & 0.958 & 1.089 & 1.39 & 0.987 \\
United States & 2000 & 0.35 & 0.958 & 0.958 & 1.089 & 1.39 & 0.987 \\
United States & 2001 & 0.35 & 0.958 & 0.958 & 1.089 & 1.39 & 0.987 \\
United States & 2002 & 0.35 & 0.958 & 0.958 & 1.089 & 1.39 & 0.987 \\
United States & 2003 & 0.35 & 0.958 & 0.958 & 1.089 & 1.39 & 0.987 \\
United States & 2004 & 0.35 & 0.958 & 0.958 & 1.089 & 1.39 & 0.987 \\
United States & 2005 & 0.35 & 0.958 & 0.958 & 1.089 & 1.39 & 0.987 \\
United States & 2006 & 0.35 & 0.958 & 0.958 & 1.089 & 1.39 & 0.987 \\
\hline
\end{tabular}

